\title{
Fossil vs. Active Geothermal Systems: A Field and Laboratory Method to Disclose the Relationships between Geothermal Fluid Flow and Geological Structures at Depth
}

\author{
Domenico Liotta ${ }^{1,2, *}$, Andrea Brogi ${ }^{1,2} \oplus$, Giovanni Ruggieri ${ }^{3}\left(\mathbb{D}\right.$ and Martina Zucchi ${ }^{1}(\mathbb{C}$ \\ 1 Dipartimento di Scienze della Terra e Geoambientali, Università degli Studi Bari Aldo Moro, Via Orabona 4, \\ 70125 Bari, Italy; andrea.brogi@uniba.it (A.B.); martina.zucchi@uniba.it (M.Z.) \\ 2 CNR-IGG, Istituto di Geoscienze e Georisorse, Via Moruzzi 1, 56124 Pisa, Italy \\ 3 CNR-IGG, Istituto di Geoscienze e Georisorse, Via La Pira 4, 50121 Firenze, Italy; giovanni.ruggieri@igg.cnr.it \\ * Correspondence: domenico.liotta@uniba.it
}

Citation: Liotta, D.; Brogi, A.; Ruggieri, G.; Zucchi, M. Fossil vs. Active Geothermal Systems: A Field and Laboratory Method to Disclose the Relationships between Geothermal Fluid Flow and Geological Structures at Depth. Energies 2021, 14, 933. https:// doi.org/10.3390/en14040933

Academic Editor: Stefano Mazzoli

Received: 2 January 2021

Accepted: 3 February 2021

Published: 10 February 2021

Publisher's Note: MDPI stays neutral with regard to jurisdictional claims in published maps and institutional affiliations.

Copyright: (c) 2021 by the authors. Licensee MDPI, Basel, Switzerland. This article is an open access article distributed under the terms and conditions of the Creative Commons Attribution (CC BY) license (https:// creativecommons.org/licenses/by/ $4.0 /)$.

\begin{abstract}
Comparison between fossil and analogue active geothermal systems permit to obtain key-parameters to define a conceptual model of the area under exploration. The approach is based on structural, kinematic, and fluid inclusions analyses. The fossil system is investigated to describe the distribution of the hydrothermal mineralization as witness of the fluid flow through geological structures and bodies, at depth. Structural and kinematic data (to define the preferential direction of fluid flow) are collected in structural stations and by scan lines and scan boxes on key outcrops. Distribution, length, width of fractures, and hydrothermal veins bring to evaluate permeability in the fossil system and, by analogy, in the deep roots of the active system. Fluid inclusions analysis shed light on density, viscosity, and temperature of the paleo-fluids. Data integration provides the hydraulic conductivity. In active geothermal systems, fieldwork is addressed to paleo-stress analysis with data from recent faults ( $<2 \mathrm{Ma})$, to compare with local focal mechanisms. By this, indications on the present fluid pathways are given. The main advantage resides in obtaining parameters normally got after drilling, thus contributing to strengthen the strategy of exploration, de-risking unsuccessful boreholes.
\end{abstract}

Keywords: structural geology; fieldwork; hydrothermal veins; geothermal systems

\section{Introduction}

One of the main obstacle to the development of the use of geothermal resources is in the cost of exploration. Failed boreholes, i.e., unproductive boreholes, can in fact negatively influence the economic plan, determining a decrease of interest on this renewable resource. Thus, the understanding of the relationships between geological structures and geothermal fluid flow is a continuous developing task in order to facilitate successful exploration. Several methodologies are dealing with this, from geochemistry (e.g., References [1,2]) to geophysical (e.g., References [3-5]), structural (e.g., References [6-8], and modeling studies (e.g., References $[9,10])$. All of these approaches are inclined to define a reliable geological and fluid-dynamic conceptual model, which will be the basis of the exploration plan and the following sustainable use of the geothermal resources.

The construction of the model is, therefore, developed before drilling. This implies a tricky point, since the model is obtained without having a direct evaluation of the siteparameters, such as fluid properties, permeability, and hydraulic conductivity, making weaker the conclusions.

In order to contribute to this gap, we describe the reliability of a field and laboratory methodology based on the coupled study of exhumed and active geothermal systems, the former analogue of the latter (Figure 1). 




Figure 1. Geological sketch (not to scale) illustrating the conceptual relationships between an analogue, exhumed, geothermal system and its related active geothermal system. The study of the fossil system takes advantage of the relationships between geological structures and hydrothermal mineralization as a key for the understanding of the relationships between geological structures and geothermal fluid flow in the active system at depth.

This approach is described comparing information from well-known geothermal systems, studied in the last years. The methodology is rooted on structural, kinematic, and fluid inclusion analyses [11-14]. The work flow is summarized in Figure 2, underlining the transfer of knowledge from the exhumed to the active system and their mutual comparison.

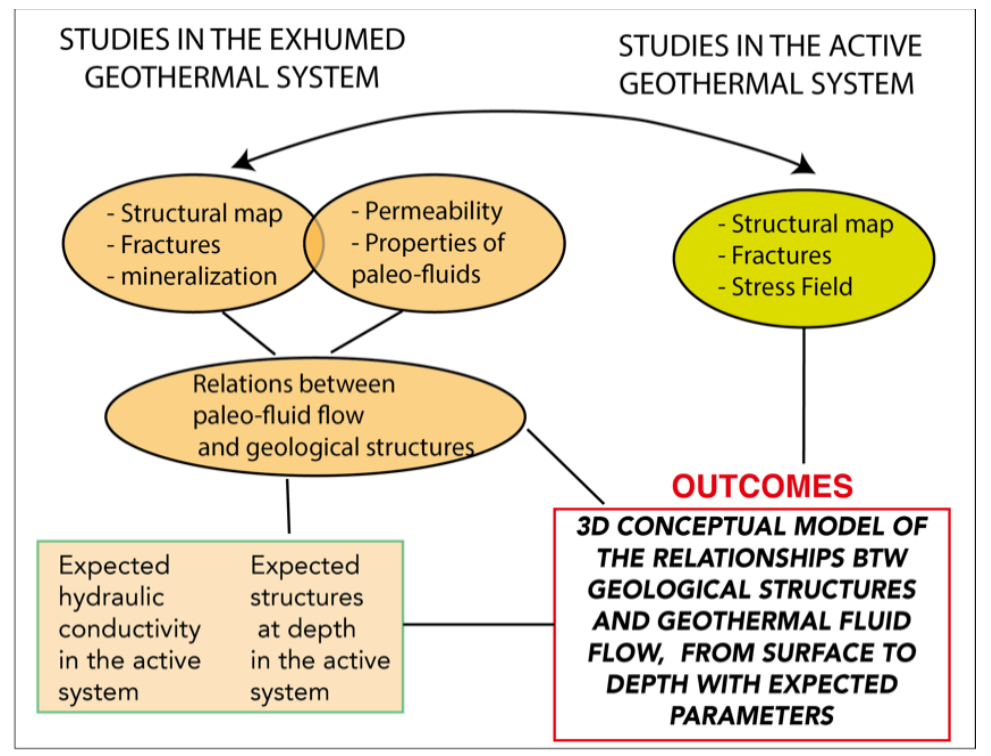

Figure 2. Sketch of the fieldwork and laboratory workflow to obtain a reliable 3D conceptual model, by transferring data from the exhumed geothermal system to the active one and by comparing fieldwork data from the active system with those from the exhumed system.

The integration among the results will permit to have: (a) a better understanding of the geological volumes hosting fluids; (b) an evaluation of the expected fluid pathways; (c) the value of the expected permeability at depth; (d) the values of the expected temperature, density and viscosity of the geothermal fluids; and (e) the value of the hydraulic conductibility. All these parameters play the role of key-factors in any predictive geothermal model, with fallouts in reducing the mining risk during the geothermal exploration. The outcomes in fact encompass a better understanding of the relationships between geological structures and fluid pathways and the values of permeability and hydraulic conductivity, that were estimated before the drilling operations.

Let us presume to have an exploration plan in a defined area. Assuming to have verified the basic conditions to have a geothermal system (e.g., heat flux, occurrence of 
an impervious cover, infiltration of meteoric water, and natural seismicity), geothermal systems are always characterized by fractures-controlled permeability $[15,16]$, mainly concentrated in: (i) damage-fault zones; (ii) at the intersection among faults segments; and/or (iii) at fault termination [17].

In this general context, two types of geothermal systems can be distinguished (Figure 3): (a) geothermal systems with a significant lateral fractured reservoir, i.e., a permeable geological body, hydraulically confined, and hydraulically connected to the main upflow structural channels; and (b) geothermal system without a significant lateral fractured reservoir. The distinction is crucial since it implies different geothermal fluid pathways and, consequently, different strategies of exploration. The knowledge of which kind of geothermal system we are dealing with, is the first result of the proposed methodological approach, described in the following.


Figure 3. Geological sketches (not to scale) illustrating the two end-member geothermal systems; left: the fluid flow is controlled by permeable fault damage zones and by a permeable level (lateral reservoir) hydraulically connected to the main structural channel. Right: the fluid flow is limited to the fault damage zone.

\section{Methodology}

The fieldwork methodology is based on field mapping and structural analyses, with collection of geometrical (e.g., fracture length and aperture; fracture and vein density) and kinematic data in structural stations (i.e., exposures where data are collected) and along scan lines in key-outcrops, coupled with mineralogical investigation, representative of the whole rocks volume, as further on described. A good knowledge of stratigraphy is a pre-requisite in order to point out possible permeable levels interbedded between impervious levels, thus considering the potential presence or absence of geothermal lateral reservoirs. It is worth to carry out the data collection both in the fossil and active geothermal area, and to maintain the comparison during the construction of the conceptual model (Figures 1 and 2). In the following, a description of the methodological approach in active and fossil systems is given, in order to have the basis for their mutual comparison, with the aim to obtain key-parameters before drilling operations.

\subsection{Active System}

A geological map of the geothermal area is the first step. The fieldwork has to be detailed, by mapping at 1:5000 scale when possible or, alternatively, at 1:10,000. Smaller scales are not suggested: fault zones (and their related permeable damage zones) in fact consist of several segments forming wide shear zones and their identification often derives from the possibility to map small geological bodies. During field mapping, an added value is to report the distribution of (i) hot springs, (ii) areas of natural gas emissions, (iii) hydrothermal alteration and mineralization, and (iv) sinter deposits (carbonate or siliceous). All of them, indicating the occurrence of fractures channeling fluids toward the surface, should find an explanation in the 3D final conceptual model. Occurrence of 
regional detachment (i.e., cataclastic) levels or continuous thick geological formation of porous lithotypes, when interbedded to less permeable levels, should be highlighted, too.

Furthermore, geothermal systems are normally persistent in the same geological region, since the tectonic conditions having brought to magmatism tend to remain stable through time [18]. If this is the case, uplift and exhumation are active, and the area under investigation can be also characterized by hydrothermal mineralization to be mapped, and/or deposits of chemical origin: in this latter case, if tectonic activity determined ruptures of the topographic surface, geothermal fluids can flow through thermal springs (Reference [19] with references therein) and produce travertine and or/silica deposits, when the geothermal fluids have an appropriate salinity [20,21]. In particular, the study of travertine, can shed light on the recent deformation, a key factor to have information on stress orientation, permeable structures and fluid-rock interactions in reservoirs at deeper levels (e.g., References [22-27]).

The mapping of brittle shear zones is accompanied by collection of structural and kinematic data, particularly on the slip-surfaces of younger faults $(<2 \mathrm{Ma})$, although data from older outcropping shear zones remain important for reconstructing the tectonic evolution of the area and for comparison with the analogue fossil geothermal system. The structural and kinematic data are crucial to derive the local stress field, active during the shear movement [28]. In fact, assuming that the measured kinematic indicators are parallel to the main shear stress, geometrical and kinematic data can derive double couplefault-plane solutions, to be compared with the present seismicity of the study area [29]. However, in terms of geothermal exploration, the most significant information is about the orientation of the intermediate stress axis, representing the main direction along which permeability [16] is favored (Figure 4) and, therefore, the main fluid flow is channeled.

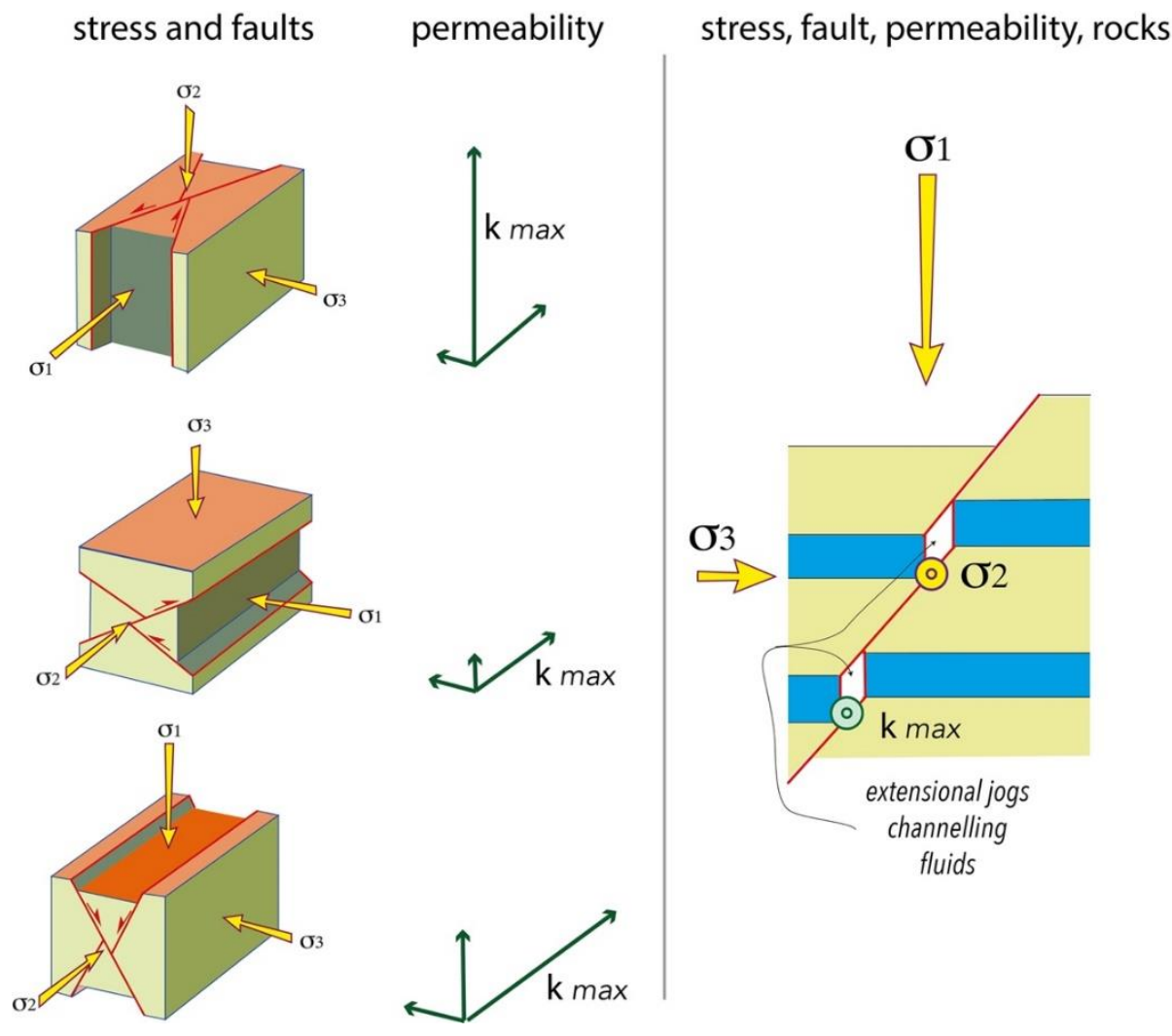

Figure 4. Relationships between the main stress axes in the Andersonian theory and the direction along which permeability (k) is favored (after Reference [29]).

Studies on density of fractures and their spatial distribution can be carried out in favorable outcrops, located along the main shear zones, in order to enforce the information 
about strain localization. We should be aware that these data, collected at surface, cannot be simply transposed to depth, since stress conditions at surface are different from those active at depth. This is a further reason why the analogue fossil system is studied: as already mentioned, the mineralized fractures give a clear information on the geometry of the fractures expected at depth.

\subsection{Fossil System}

A fossil geothermal system is an exhumed geothermal system, defined by outcrops of: (i) mineralized fractures (epi- and meso-thermal extensional and shear veins), (ii) mineralized geological bodies; and, when exhumation is significant, and (iii) exposures of granitoids, representative of the heat source. Thus, the fossil, exhumed, system gives a view on the deep roots of a geothermal system, permitting a better understanding of the relationships between geological structures and geothermal fluid pathways at depth (Figure 1), the latter represented by hydrothermal veins and mineralized geological bodies.

Three main conditions should be satisfied, before defining a fossil geothermal system as analogue of the active one (Figure 1): (a) the active and fossil systems should be part of the same tectonic context; (b) the tectonic context remained unchanged in the time range between the formation of the fossil and active geothermal systems; and (c) the succession of basement rocks is the same in both systems and the sedimentary cover is similar, as well.

Once these conditions are established, the study of the fossil system can be approached, finalized to the reconstruction of the relationships between geological structures and hydrothermal mineralization, as a key for the understanding the deep circulation in the active system. The study of this relation takes advantage by the fact that the fractures are sealed by hydrothermal minerals, thus giving a picture of the loci where circulation was active.

Analogue fossil system can, therefore, explain which typology of geothermal system we are dealing with (Figure 3). In the case of absence of lateral reservoir, mineralization will be only located in fault damage zones, or along pre-existing discontinuities (i.e., bedding and/or foliation) of the hosting rocks; in the case of a lateral reservoir, instead, large mineralized bodies will be recognizable, in correspondence of stratigraphic, permeable, levels.

The method of studying fossil systems is based on fieldwork and laboratory analyses. In the field, the activity consists on mapping geological bodies and structures at 1:5000 or 1:10,000 scale, highlighting the distribution of veins and of the mineralized geological bodies, both testifying the pathways of the fluids. To this goal, structural stations and scan lines will implement the dataset, by reporting data on density of fractures, shear veins and their distribution; particular attention should be given to kinematics of brittle, mineralized, shear zones in order to have insights on the orientation of the preferential structural channels [11-13,30-32]. In this context, data to evaluate permeability are also obtained, as later on described. Laboratory activity mainly consists of petrographic and mineralogical study of both rocks and veins, and fluid inclusions analyses on hydrothermal minerals. From this study, physical and chemical characteristics of the analogue paleofluids are derived.

\subsubsection{Permeability}

The study of the fossil, analogue, geothermal system contributes to the construction of the conceptual model on the relationships between geological structures and geothermal fluid flow and provides key-parameters, such as the estimation of fracture-permeability and localization of favored permeability.

Permeability can be computed assuming a parallel plate model, although fractures with permeability $\mathrm{k}>10^{-12} \mathrm{~m}^{2}$ cannot be approximated by this model [33,34]. Hence, a laminar flow and a network of fractures with different orientations, apertures, and spacing is, therefore, considered $[33,35,36]$. In evaluating the fracture network connectivity, Reference [34] approximated the fracture roughness and internal connectivity as a series of angles among rock- wedges, expressing the efficiency with values comprised between 1 
and 0.1 . They demonstrated that if wedges have a connecting angle lower than $30^{\circ}$, then the relative transmissivity is reduced at most by a factor of 0.7 ; in contrast to a connecting angle of $60^{\circ}$ where reduction is by a factor of 0.4 . Based on these considerations, the following relation can be derived [12,13]:

$$
k=\left(\frac{2}{3} \times \frac{b^{3}}{L}\right) \times\left(f \times 10^{-6}\right),
$$

where $k$ is permeability $\left(\mathrm{m}^{2}\right), b$ and $L$ are the mineralized vein width and length $(\mathrm{m})$, respectively. These two latter parameters can be measured in the field or in laboratory, by means of image analysis software. $f$ is the factor expressing fracture connectivity that can be assumed as 0.4 , since its value is negligible on the final result. Finally, the dimension $10^{-6}$ derives from studies on the effective hydraulic aperture of experimental flow data, considering different roughness of the wall fractures [34].

Collection of data is, therefore, finalized to have length and width of the mineralized veins. The procedure implies scan lines and scan boxes in key-outcrops (Figure 5), located along the main shear zones affecting the study area $[12,13]$. The use of the scan box is the space reference for the measurement of length and width of fractures.


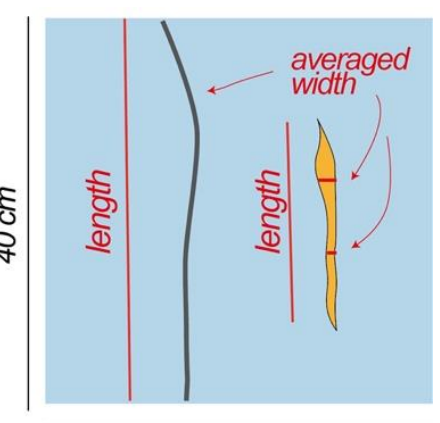

$40 \mathrm{~cm}$

Figure 5. Sketch illustrating the methodology of scan line and scan box to collect data for the computation of permeability, considering width and length of fractures and veins, as recognized in a square of $40 \mathrm{~cm}$ per side. The scan line is settled after a detailed geological survey in the chosen key-area: along the line, the frequency of fractures is considered. The scan box is moved aside regularly along the scan line and data are collected (manually or by analyzing photos by image software) in each new location of the scan box.

Each scan box provides averaged values of $b, L$, and then $k$, assumed as representative of that volume of rock. Each scan line, having several scan-boxes, will give a variety of permeability values, as a function of density and aperture of veins. A statistical assessment can be therefore necessary. Finally, since mineralized veins can derive from multiple injections and be very wide, values of $k \geq 1^{*} 10^{-12} \mathrm{~m}^{2}$ are excluded because unreasonable for a single event. Moreover, similar permeability values overtake the limits of the plate model theory, that is at the base of these evaluations.

\subsubsection{Properties of the Paleo-Fluids}

Physical-chemical features of paleo-fluids are obtained from the study of fluid inclusions trapped in hydrothermal minerals during their crystallization. Fluid inclusions, in fact, are small portions of fluid (liquid, vapor, or supercritical fluid) entrapped within crystals during its primary growth and/or after its complete deposition [37-42]. If more than one generation of fluid inclusions are trapped within a single mineral or in mineral 
assemblage, the temporal relationships between the different inclusion generations can provide information on the evolution of the paleo-fluids with time.

The most common technique for fluid inclusion studies is given by microthermometric analyses based on the measurement of the temperature at which some phase changes take place in inclusions during heating and cooling cycles. If the analyzed fluid inclusions satisfy the three rules reported by Reference [37] (i.e., the inclusions trapped a single, homogeneous phase; the inclusions represent an isochoric system after trapping; nothing has been added to, or removed from the inclusions) the data collected by this non-destructive technique allows to get some properties of the original trapped fluid. In particular, for inclusions containing aqueous solution it provides fluid density and salinity (expressed in wt.\% of $\mathrm{NaCl}$ equivalent). Fluid inclusions analysis can be also supported by others laboratory techniques, such as micro-Raman spectroscopy, laser ablation inductively coupled plasma mass spectrometry (LA-ICP-MS), which provide information on the composition of volatile phase and of the aqueous liquid phase [42].

If fluid inclusions were trapped when two immiscible fluids coexist (for example, when aqueous liquid and vapor phases contemporaneously occur during boiling), trapping temperature can be obtained directly from microthermometric data (i.e., it corresponds to the homogenization temperature), whereas pressure can be computed from this temperature by using two-phase pressure-temperature relation. However, usually fluid inclusions are trapped when only a single homogeneous fluid (liquid or vapor or supercritical) is present, but, in this case the homogenization temperature represents the minimum trapping temperature. For these inclusions, trapping temperature (or pressure) can be obtained from their isochores if an independent pressure (or temperature) estimate is available. For inclusions containing aqueous solution, isochores can be computed from density (or homogenization temperature) and salinity data by using equations of state or from experimental data [43,44]. Density and viscosity of the paleo-fluids can be also estimated by using existing equations proposed by References [45,46], based on the $\mathrm{H}_{2} \mathrm{O}-\mathrm{NaCl}$ Equation of State, as proposed by Reference [47], after Reference [48].

\subsubsection{Fossil vs. Active Systems}

An evaluation of the reliability of the results is obtained by comparing fossil and active systems studies. This is carried out by checking: (a) geological structures, as these resulted from the field mapping in both systems. The geometrical coherence of structures is definitely the first requirement to assess a common tectonic evolution; (b) kinematics, paleo-stress analyses can be carried out in both systems, and then compared with the local focal mechanisms. If consistence is proved, then a more robust consideration on the relations between fluid path, and geological structures is reached, positively applying the lesson learnt from the fossil system; and (c) geometries of structures at depth in the active system, as derived on the basis of the direct data observed in the fossil system, considered the analogue of the deep part of the active system. Obviously, this transfer of knowledge (i.e., from fossil to active system) should be then checked with information from borehole logs, geophysics and geochemistry carried out in the active system, in case of availability (e.g., References [49-52]).

\section{Case Histories}

Examples of the methodology above proposed, are here below summarized, illustrating two different cases, respectively, referred to the presence and absence of a lateral fractured reservoir.

\subsection{Occurrence of Lateral Reservoir: Elba and Larderello Geothermal Systems}

Both areas are located in the inner Northern Apennines, a former collisional belt (Cretaceous-early Miocene), now experiencing extensional tectonics (Miocene-Present). Extension is eastward migrating $[53,54]$ and, since late Miocene, it is associated to eastward migrating magmatism [55]. This latter determined a widespread hydrothermal mineraliza- 
tion, as it is the case of southern Tuscany and Elba Island [56] and presently gives rise to active geothermal systems (e.g., Larderello) and thermal springs [57,58]. The emplacement of magmatic bodies, volcanism and geothermal manifestations has been controlling by NE-trending transfer zones [59] of which activity is coeval with the NW-trending normal faults (Figure 6).


EARLY - MIDDLE MIOCENE
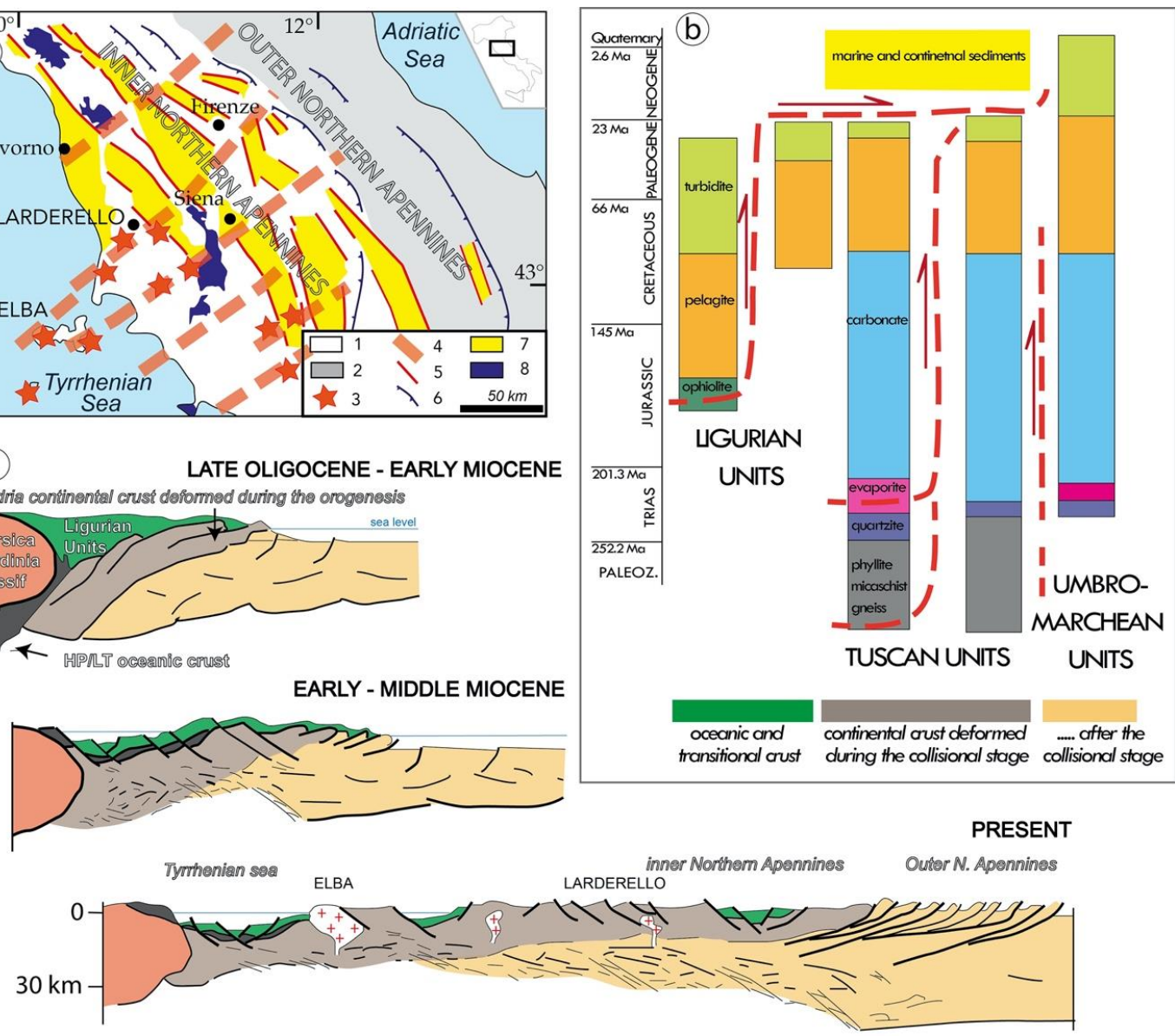

Figure 6. Geological sketches and map illustrating the evolution of Northern Apennines: (a) Structural sketch map showing the relationships between the main Pliocene-Pleistocene basins and transfer zones in Tuscany. Symbols: 1-inner Northern Apennines: this domain is characterized by a 22-24 thick crust; 2-outer Northern Apennines with a 35-40 thick crust; 3-Outcropping or drilled magmatic bodies; these are mainly located along the transfer zones (after References [59,60]); 4-transfer zones; 5-normal faults; 6-thrusts; 7-Pliocene-Pleistocene marine to continental sediments; 8-metamorphic rocks; (b) relationship between the different tectonic units of inner northern Apennines and related paleogeographic domains. (c) Schematic geological cross-sections showing the collisional and post-collisional evolution in the inner zone of the northern Apennines (after References [60,61]).

The tectonic evolution of the inner Northern Apennines is then characterized by detachment levels, playing a role both during compression and extension; one of the main detachment is located at the base of the Jurassic-Miocene sedimentary cover, implying that the Triassic rocks are deeply affected by tectonic brecciation (Figure 6), thus determining lateral permeable levels where old and present geothermal fluids flew and flow, chemically interacting with the hosting rocks. Hence, Elba and Larderello are located in the same tectonic context and their rock-succession is comparable [60-62], belonging to the same paleogeographic domains and tectonic evolution [31]. Furthermore, eastern Elba is characterized by a widespread Fe-oxides and hydroxides mineralization, connected to the hydrothermal activity developed during the cooling of the mid-crustal Porto Azzurro monzogranite, dated at $6.53 \pm 0.39 \mathrm{Ma}$ [63]. Similarly, the active Larderello geothermal 
system is sustained by a mid-crustal cooling granitoid, recognized through geophysical methods [64] and petrological considerations [58]. Exhumation and uplift processes determined the exposure of the deep roots of the Elba geothermal system, thus shedding light on the Larderello geothermal system at depth, by analogy.

\subsubsection{Elba Island}

Based on these considerations, the relationships among mineralized faults, hydrothermal veins distributions, heat source, ore bodies, and geological structures were studied $[12,14,58,65]$. Existing data converge to indicate that the Porto Azzurro monzogranite emplaced in a transfer zone [12,31,59], affecting the southeastern side of the Elba Island (Figure 7). Within this transfer zone, at least $3 \mathrm{~km}$ width, the structural and kinematic studies highlighted the presence of different generation of faults and related fault damage zones. These are characterized by mineralized shear veins where the hydrothermal phases are often cataclastic, testifying the contemporaneity between fluid flow and fault activity. Hydrothermal mineralization is defined by a variety of mineral assemblages depending on the paleo-fluid temperature and chemistry, the latter largely influenced by its origin (magmatic, meteoric and/or a mixing of both), pressure conditions, and structural level of the geothermal system (from deeper to shallower) where the fluid circulation occurred.

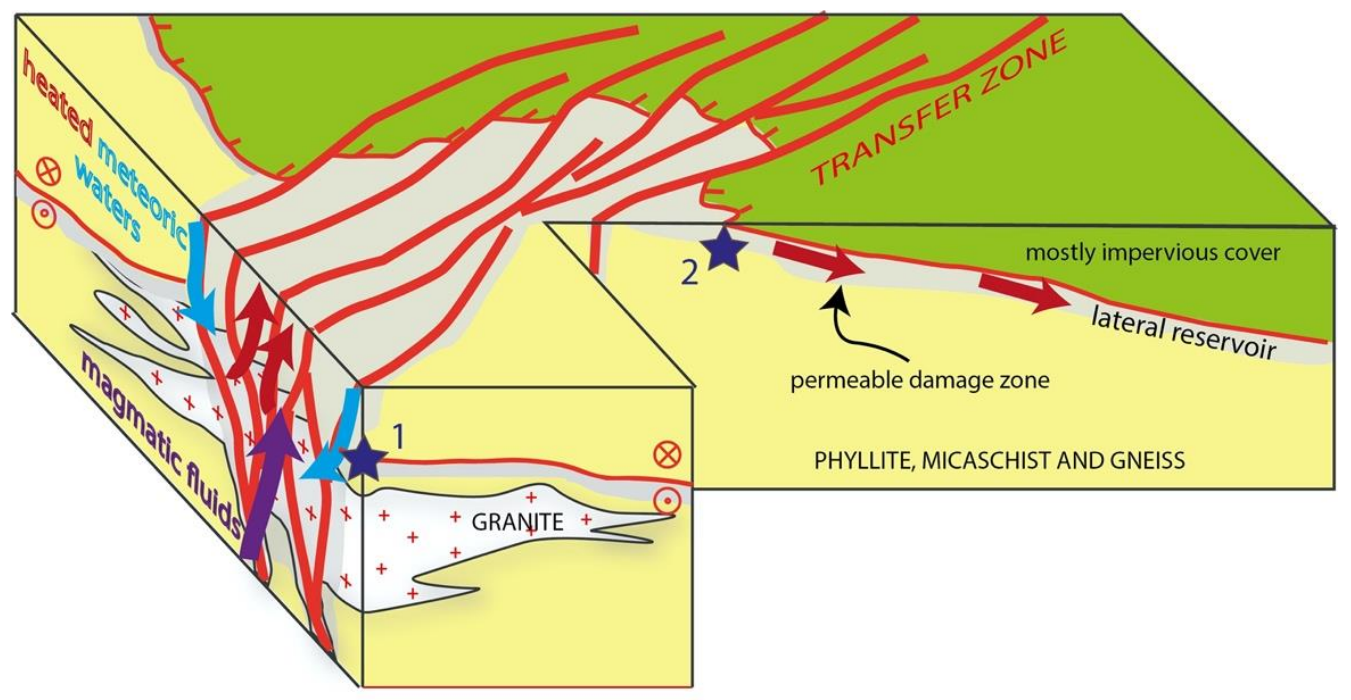

Figure 7. Structural sketch (not to scale) illustrating the relationships between geological structures, magma emplacement, and geothermal fluid flow (generating hydrothermal minerals) in the eastern Elba Island. Magmatic and geothermal fluids are channeled in the brittle transfer zone, and then stored in lateral reservoir. The structural location of the two areas described in the text are indicated: 1-deeper structural level, within micaschist; 2-shallower level, within quartzite Triassic rocks (after Reference [66]).

At Elba island, the deeper structural level affected by geothermal circulation, is made up of Paleozoic micaschist, hosting the Porto Azzurro magmatic intrusion. In this level, characterized by low and very-low permeability, fluid circulation was mainly linked to fractures (Figure 8a-e). Thus, interaction between fluid and rock is limited to the wallfractures, causing a halo of alteration (Figure 8f), determined by the leaching of biotite and tourmaline deposition, mostly $[67,68]$. At this structural level, the typical mineral assemblage filling the majority of shear veins is made up of tourmaline, mainly of schorl and dravite composition, and minor amount of quartz $[12,68]$. Tourmaline is polyphasic and cataclastic, hence indicating a continuous activity of the faults during crystallization and fluid flow (Figure $8 \mathrm{~g}-\mathrm{h}$ ). Occurrence of hydraulic breccias indicate the role in fault weakening and permeability enhancement exerted by the fluid pressure during fault activity (Figure 8i). Two main systems of tourmaline mineralized faults were recognized, both cross cut by quartz shear veins (Figure 9). Kinematic analyses indicate that the first 
generation of faults is mostly defined by low-angle dominantly normal faults whereas the second generation is typified by almost vertical faults, with a significant transcurrent component. The contemporaneity between these two fault-systems is marked by the common occurrence of tourmaline (i.e., the same hydrothermal fluid) in both fault systems. It implies that deep fluids can find favorable permeable structural conduits along the almost vertical and low-angle shear zones, on the basis of the orientation of their related intermediate stress axes. Finally, the third deformational event is defined by small quartz shear vein, with rare kinematic indicators, pointing to a dominant normal component of movement [12].
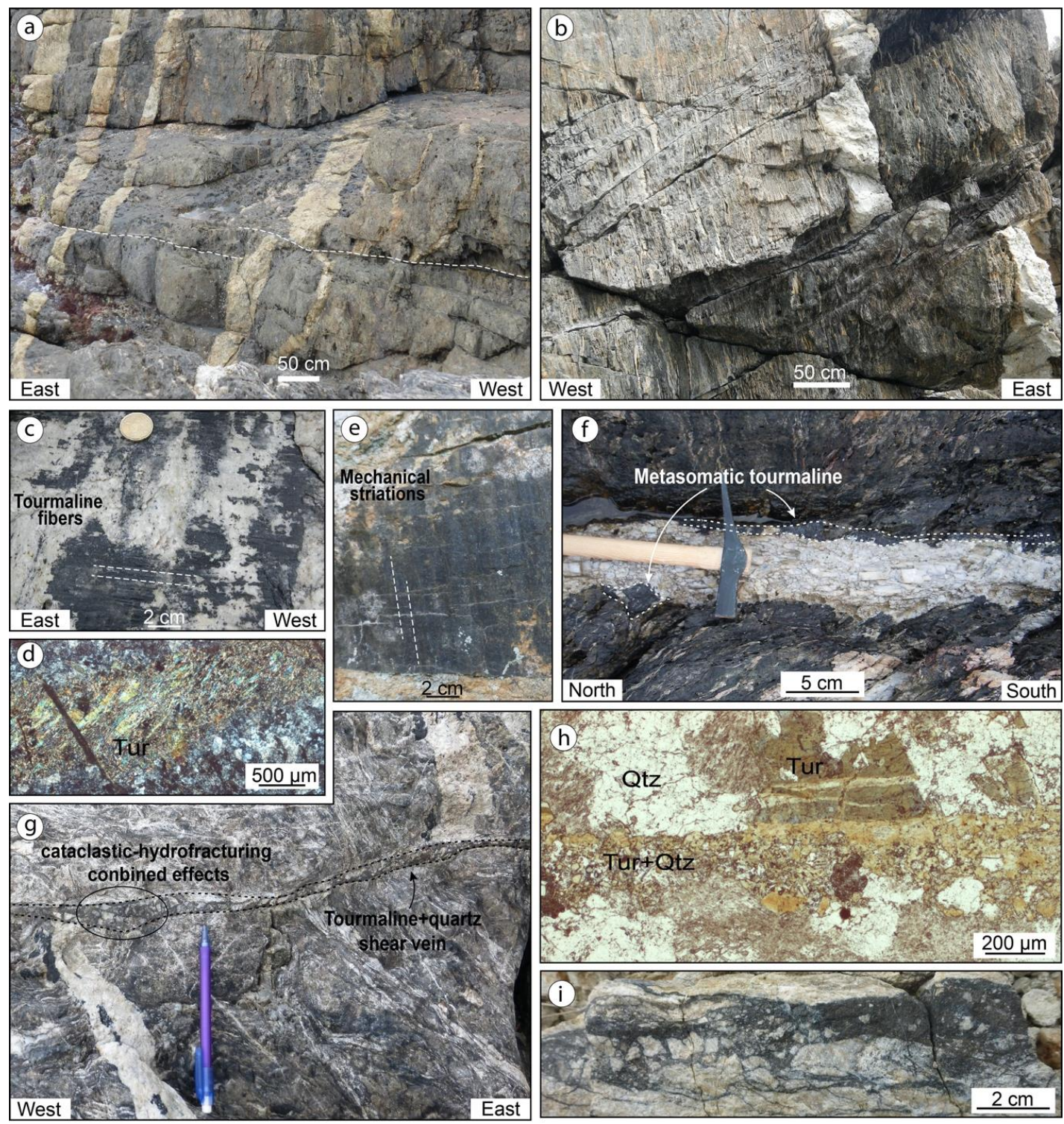

Figure 8. Faults and hydrothermal tourmaline shear veins in the Paleozoic micaschist. (a) Low-angle normal fault affecting Late Miocene leucogranite dykes; (b) fault slip-planes are characterized by tourmaline shear veins, crosscutting the leucogranite dykes; (c-e) tourmaline slickenlines on fault slip plane, with oblique- or normal slip movement; the thin section shows the dominant cataclastic texture of tourmaline, indicating syn-tectonic mineralization; (f) tourmaline-bearing metasomatic halos bounding a leucogranite dyke intruding the micaschist; (g) shear vein with tourmaline and quartz clasts deriving from cataclastic and hydrofracturing effects; (h) micrograph (plane polarized light) of neoformational tourmaline characterized by pale blue zonation due to the different composition (from schorl to dravite), and shear vein made up of cataclastic tourmaline; (i) detail of hydraulic breccia cemented by tourmaline and quartz; Mineral abbreviation from Reference [70]. 

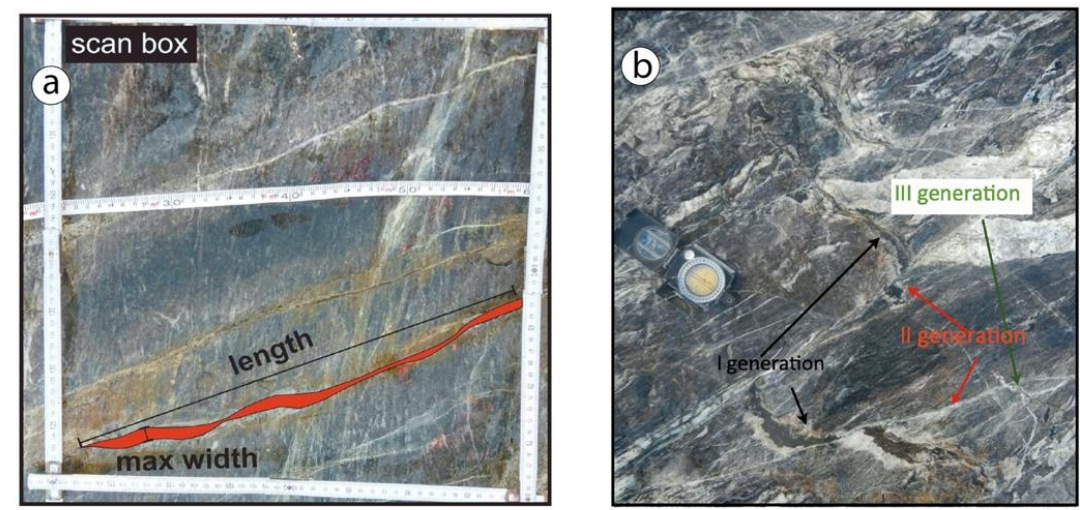

(C)

\begin{tabular}{|c|c|c|c|c|c|c|c|c|c|c|}
\hline SCAN LINE & SCAN BOX & $\begin{array}{c}\text { FRACTURE } \\
\text { GENERATION }\end{array}$ & $\begin{array}{l}\text { DISTANCE FROM } \\
\text { THE ORIGIN OF THE } \\
\text { SCAN LINE }\end{array}$ & $\begin{array}{c}\text { NUMBER } \\
\text { OF } \\
\text { FRACTURES }\end{array}$ & $\underset{(m)}{\min \text { WIDTH }}$ & $\begin{array}{l}\max \text { WIDTH } \\
(\mathrm{m})\end{array}$ & $\begin{array}{l}\text { average } \\
\text { WIDTH }\end{array}$ & $\begin{array}{l}\text { LENGTH } \\
(\mathrm{m})\end{array}$ & $k\left(m^{2}\right)$ & $\begin{array}{l}\text { k (harmonic } \\
\text { average) }\end{array}$ \\
\hline \multirow[t]{14}{*}{ A } & 6 & 1 & 5.7 & 1 & 0.0015 & 0.004 & 0.00275 & 0.192 & $2.89 * 10^{-14}$ & $2.89 * 10-14$ \\
\hline & & & & & & & & & & \\
\hline & & IIII & 5.7 & 1 & 0.0001 & 0.0002 & 0.00015 & 0.046 & $1.96 * 10^{-17}$ & \\
\hline & & & & 2 & 0.0001 & 0.0015 & 0.0008 & 0.026 & $5.25 * 10^{-15}$ & \\
\hline & & & & 3 & 0.005 & 0.002 & 0.00125 & 0.13 & $4.01 * 10^{-15}$ & $5.81 * 10^{-17}$ \\
\hline & & & & & & & & & & \\
\hline & 8 & 1 & 7.7 & 1 & 0.001 & 0.004 & 0.0025 & 0.038 & $1.1 * 10^{-13}$ & \\
\hline & & & & 2 & 0.0002 & 0.0065 & 0.00335 & 0.14 & $7.16 * 10^{-14}$ & \\
\hline & & & & 3 & 0.0005 & 0.0025 & 0.0015 & 0.08 & $1.12 * 10^{-14}$ & \\
\hline & & & & 4 & 0.0001 & 0.0055 & 0.0028 & 0.184 & $3.18 * 10^{-14}$ & \\
\hline & & & & 5 & 0.0002 & 0.0065 & 0.00335 & 0.16 & $6.26 * 10^{-14}$ & $3.14 * 10^{-14}$ \\
\hline & & & & & & & & & & \\
\hline & & III & 7.7 & 1 & 0.0005 & 0.0015 & 0.001 & 0.078 & $3.41 * 10^{-15}$ & \\
\hline & & & & 2 & 0.0001 & 0.002 & 0.00105 & 0.27 & $1.14 * 10^{-15}$ & $1.71 * 10^{-15}$ \\
\hline
\end{tabular}

(d)

\begin{tabular}{|c|c|c|c|c|}
\hline $\begin{array}{c}\text { GENERATION OF } \\
\text { FRACTURES }\end{array}$ & $\operatorname{min~} \mathbf{k}\left(\mathbf{m}^{2}\right)$ & $\operatorname{max~k}\left(\mathbf{m}^{2}\right)$ & $\begin{array}{c}\mathbf{k} \\
\text { (geometric } \\
\text { average) }\end{array}$ & $\begin{array}{c}\text { Mineral } \\
\text { phase }\end{array}$ \\
\hline & & & & \\
\hline I & $5^{*} 10^{-16}$ & $5^{*} 10^{-14}$ & $9.2^{*} 10^{-15}$ & Tourmaline \\
\hline II & $5^{*} 10^{-14}$ & $5 * 10^{-13}$ & $2.2^{*} 10^{-14}$ & Tourmaline \\
\hline & & & & \\
\hline III & $5^{*} 10^{-17}$ & $5^{*} 10^{-15}$ & $7.7^{*} 10^{-17}$ & Quartz \\
\hline
\end{tabular}

(e)

\section{LARDERELLO: \\ $k=1 * 10^{-14}-1 * 10^{-15}$}

Figure 9. How to get permeability values in the field: (a) photo illustrating the scan box and the parameters to be collected; (b) in the study area, three different generation of mineralized veins have been recognized; (c) example of collection of data and related database; (d) values of permeability, after having considered the average among all the data; (e) data of permeability measured in the active geothermal field of Larderello, for comparison with the obtained data; after Reference [69]. The asterisk indicates the multiplication sign.

In key-outcrops, estimation of permeability (Figure 9) was carried out for the three different fractures systems. Permeability values are in the order of $10^{-14}-10^{-15} \mathrm{~m}^{2}$, for the tourmaline veins (same range of the present measured permeability in Larderello [51,69]); differently, permeability is in the order of $10^{-17} \mathrm{~m}^{2}$ for the quartz veins, referred to the third deformational event. Concluding, it implies that heat transfer occurred by convection during the development of the tourmaline fractures, and by conduction during the development of the third family of fractures [6].

Fluid inclusions analysis, carried out on hydrothermal tourmaline and quartz, highlighted that two main fluid types with distinct salinities circulated within these shear zones: (i) a hypersaline fluid with salinity from 29 to $49 \mathrm{wt} . \% \mathrm{NaCl}$ equivalent; and (ii) a less saline fluid with salinity between 16 and $30 \mathrm{wt} . \% \mathrm{NaCl}$ equivalent. The trapping pressure-temperature ranges of the two fluid types were computed by Reference [12] from homogenization temperature and pressure data, inclusion representative isochores and the maximum pressure-temperature $\left(200 \mathrm{MPa}\right.$ and $\left.650{ }^{\circ} \mathrm{C}\right)$ of thermometamorphism related to the Porto Azzurro monzogranite emplacement reported by Reference [71]. In particular, the maximum temperatures are from 370 to $450{ }^{\circ} \mathrm{C}$ and from 380 to $650{ }^{\circ} \mathrm{C}$ for hypersaline, 
and less saline fluids, respectively (see Figure 9 of Reference [12]). Salinity and temperature data suggest a magmatic origin for both fluid types.

Computing density and viscosity by existing equations [45-48], and considering permeability values, the hydraulic conductivity was evaluated at the minimum and the maximum trapping pressure conditions of fluid inclusions (Figure 10).

\begin{tabular}{|c|c|c|c|c|c|c|c|c|c|c|}
\hline \multirow{2}{*}{$\begin{array}{l}\text { FAULT } \\
\text { GENERATION }\end{array}$} & \multirow{2}{*}{$\begin{array}{l}\text { FLUID } \\
\text { INCLUSION } \\
\text { TYPE }\end{array}$} & \multicolumn{3}{|c|}{$\begin{array}{l}\text { VISCOSITY }(\eta) \\
\left(\mu \mathrm{Pa}^{*} \mathrm{~s}\right)\end{array}$} & \multicolumn{2}{|c|}{$\begin{array}{l}\text { DENSITY }(\rho) \\
\left(\mathrm{kg} / \mathrm{m}^{3}\right)\end{array}$} & \multicolumn{2}{|c|}{$\begin{array}{l}\text { PERMEABILITY (k) } \\
\qquad\left(\mathrm{m}^{2}\right)\end{array}$} & \multicolumn{2}{|c|}{$\begin{array}{l}\text { HYDRAULIC CONDUCTIVITY (K) } \\
\qquad(\mathrm{m} / \mathrm{s})\end{array}$} \\
\hline & & low-pressu & ure range & high-pressure range & $\min$ & $\max$ & $\max$ & $\min$ & low-pressure range & \begin{tabular}{|l|} 
high-pressure range \\
\end{tabular} \\
\hline 1 & $\mathrm{~L}$ & $3.29 * 10^{+01}$ & $5.91 * 10^{+01}$ & $7.06^{*} 10^{+01} 1.24^{*} 10^{+02}$ & 661 & 889 & $5.00 * 10^{-14}$ & $5.00 * 10^{-16}$ & $1.00^{*} 10^{-09} 8.26^{*} 10^{-12}$ & $4.68^{\star} 10^{-10} 3.94^{*} 10^{-12}$ \\
\hline \multirow{2}{*}{ II } & $\mathrm{L}$ & $3.29 * 10^{+01}$ & $5.91 * 10^{+01}$ & $7.06 * 10^{+01} \quad 1.24 * 10^{+02}$ & 661 & 889 & $5.00^{*} 10^{-13}$ & $5.00 * 10^{-14}$ & $1.54^{*} 10^{-08} 1.76^{*} 10^{-09}$ & $7.19^{*} 10^{-09} 8.41 * 10^{-10}$ \\
\hline & s & $3.88^{*} 10^{+01}$ & $2.40 * 10^{+02}$ & $1.91 * 10^{+02} 2.78^{*} 10^{+02}$ & 1105 & 1142 & $5.00 * 10^{-13}$ & $5.00 * 10^{-14}$ & $1.31^{*} 10^{-08} 4.34^{*} 10^{-10}$ & $2.65^{\star} 10^{-09} 3.75^{*} 10^{-10}$ \\
\hline III & $\mathrm{L}$ & $2.72^{*} 10^{+01}$ & $4.81 * 10^{+01}$ & $9.56 * 10^{+01} \quad 1.61 * 10^{+02}$ & 777 & 1029 & $5.00 * 10^{-15}$ & $5.00 * 10^{-17}$ & $1.43^{*} 10^{-10} 1.07 * 10^{-12}$ & $4.06 * 10^{-11} 3.19 * 10^{-13}$ \\
\hline
\end{tabular}

Figure 10. Minimum and maximum values of fluid viscosity and density, and of permeability and hydraulic conductivity for the different generation of fractures in the micaschist, as based on the parameters obtained by field and laboratory analyses. Symbols: L-liquid phase; S-solid phase (after Reference [12]). The asterisk indicates the multiplication sign.

Concluding, the deeper structural level of the exhumed system is characterized by fluids of magmatic origin, of which circulation is only controlled by fracture permeability along almost vertical and horizontal channels.

Elba even shows a shallower mineralized level, where circulation of paleo-fluids is documented, presently corresponding with the Fe-ore body. This is hosted in the Triassic dominantly quartz-rich rocks (metaconglomerate, quartzite, and phyllite: Verrucano Fm. Auct.), affected by brittle deformation both during the collisional and extensional stages. This level hosts a cataclastic horizon that is hydraulically connected to the southern transfer zone $[31,66]$ affecting the Elba Island (Figure 6). Fault systems of this shallower structural level of Elba are kinematically similar to those affecting the deeper level [66]: coeval evolution of almost perpendicular faults with different kinematics, is in fact documented in the frame of oblique-slip (i.e., transfer) and normal faults. Moreover, faults with oblique movement are later affected by normal movement [66].

In the Triassic level, hydrothermal fluids flew through fractures (Figure 11a), permeating the quartz-rich rocks through the matrix, producing metasomatic bodies overall replaced by Fe-oxide and sulphide [72]. In this process, the texture of the quartzite rock is crucial, resulting metasiltite almost impervious to the fluid flow (Figure 11b). Pre-existing mechanical discontinuities (i.e., foliations) influenced fluid flow, too (Figure 11c,d). If foliations are pervasive and texture is favorable, then a complete metasomatic process developed (Figure 11e). As already seen in the deeper micaschist level, even here fluid flow is contemporaneous to fault-movements, as testified by Fe-oxides and adularia shear veins on fault-slip surfaces (Figure 11f,g). Fluid inclusions analysis mainly carried out on hydrothermal quartz, calcite and adularia indicate homogenization temperature values up to $330^{\circ} \mathrm{C} \mathrm{[73]} \mathrm{and} \mathrm{variable} \mathrm{salinities} \mathrm{up} \mathrm{to} 22 \mathrm{wt} . \% \mathrm{NaCl}$ equivalent [66]. These values point to a mixing between magmatic fluid and meteoric water, as it is reasonable, being closer to the surface. Hence, fluids were here stored determining a lateral reservoir, passing through pre-existing discontinuities and/or reacting with the rock-matrix of the Triassic level. The process was active up to the fluid was renewed and permeability maintained by fractures (i.e., seismicity) and chemical fluid-rock interaction.

In conclusion, the fossil system of Elba tells us that fluid circulation occurred at two different levels, mostly: in the deep rocks (micaschist) and at shallower level, in the permeable Triassic rocks with permeability values that permitted heat transfer by convection. Paleo-fluids characteristics indicate a magmatic contribution at deeper structural levels, while the contribution of meteoric waters became significant approaching the surface. Keeping in mind this information, we move to the active system. 

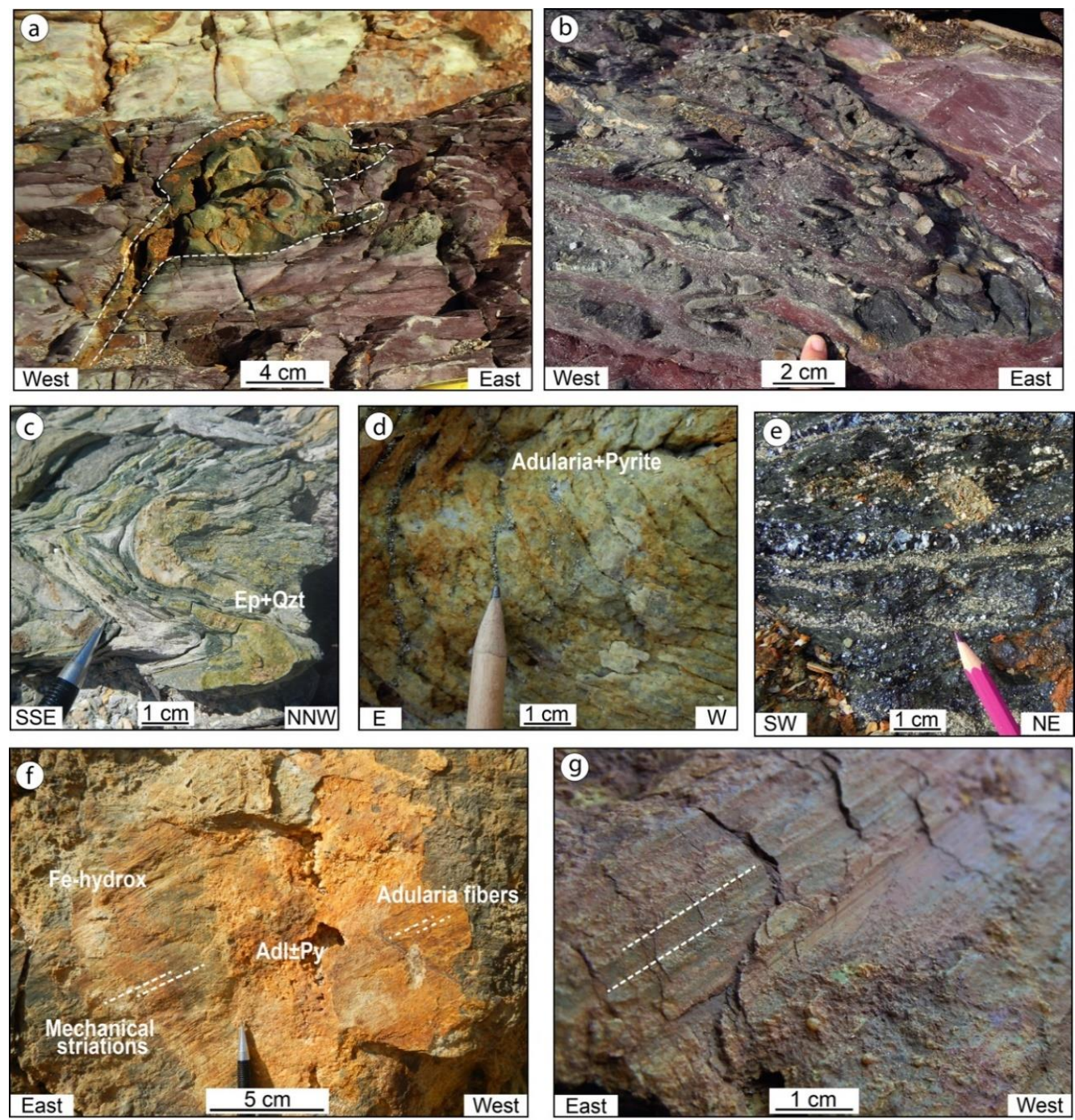

Figure 11. Photos of outcrops of Fe-oxides and Fe-hydroxides bearing quartzite; (a) Fe-hydroxide vein settled along a fracture: the paleofluid laterally migrated, where the texture of the rock was suitable to host fluid flow; (b) the metasomatic process is selective, being efficient in the quartz-metasandstone only, while phyllite (violet) remains basically impervious; (c) detail of former sedimentary levels selectively metasomatized by epidote and quartz; (d) pyrite and adularia veinlets along the foliation of quartzite: the fluid flow followed pre-existing discontinuities; (e) metasomatism affects the entire level, thus forming an ore deposit of pyrite and hematite; (f) fault slip surface characterized by syn-kinematic adularia and Fe-hydroxides fibers and mechanical striations; (g) example of dominant oblique slip movement in a fault-plane Fe-hydroxide shear vein. Mineral abbreviation from Reference [70]).

\subsubsection{Larderello Geothermal System}

The Larderello geothermal system includes several geothermal fields, distributed in an almost $120 \mathrm{~km}^{2}$. On the whole, two different reservoirs have been detected. The shallower, named as "first reservoir" (depth about 800-1000 m), is located at the base of the sedimentary cover, within the cataclastic level corresponding to the late Triassic evaporite. This is the historical reservoir. The deeper reservoir, named as "deep reservoir", is hosted in micaschist and/or phyllite, at a depth ranging between 3 and $4 \mathrm{~km}$ [74]. Temperature is $220-250{ }^{\circ} \mathrm{C}$ in the shallower reservoir, while it is $300-350{ }^{\circ} \mathrm{C}$ in the deeper one [51]. Properties of fluids indicate a dominant meteoric origin [51].

We focus on the Lago geothermal field (Figure 11), that is the most efficient one of the Larderello production area, where the magma source is supposed to be located at about 4 $\mathrm{km}$ depth [51], thus explaining the local high heat flux, the values of the ${ }^{3} \mathrm{He} /{ }^{4} \mathrm{He}$ ratio 
(Figure 12), and the shallow depth of the brittle/ductile transition [75-77]. Structural data collection in the area was recently carried out [29], providing a new geological map and kinematic data from structures considered active in the last $2 \mathrm{Ma}$. This information brought to the: (a) definition of the main geological structures and their role, highlighting two coeval fault systems framed in the evolution of a transfer zone; and (b) paleo-stress analysis from inversion of kinematic data, in order to have comparison with the local seismicity and define the orientation of the intermediate stress axis, during the kinematic evolution (Figure 12).
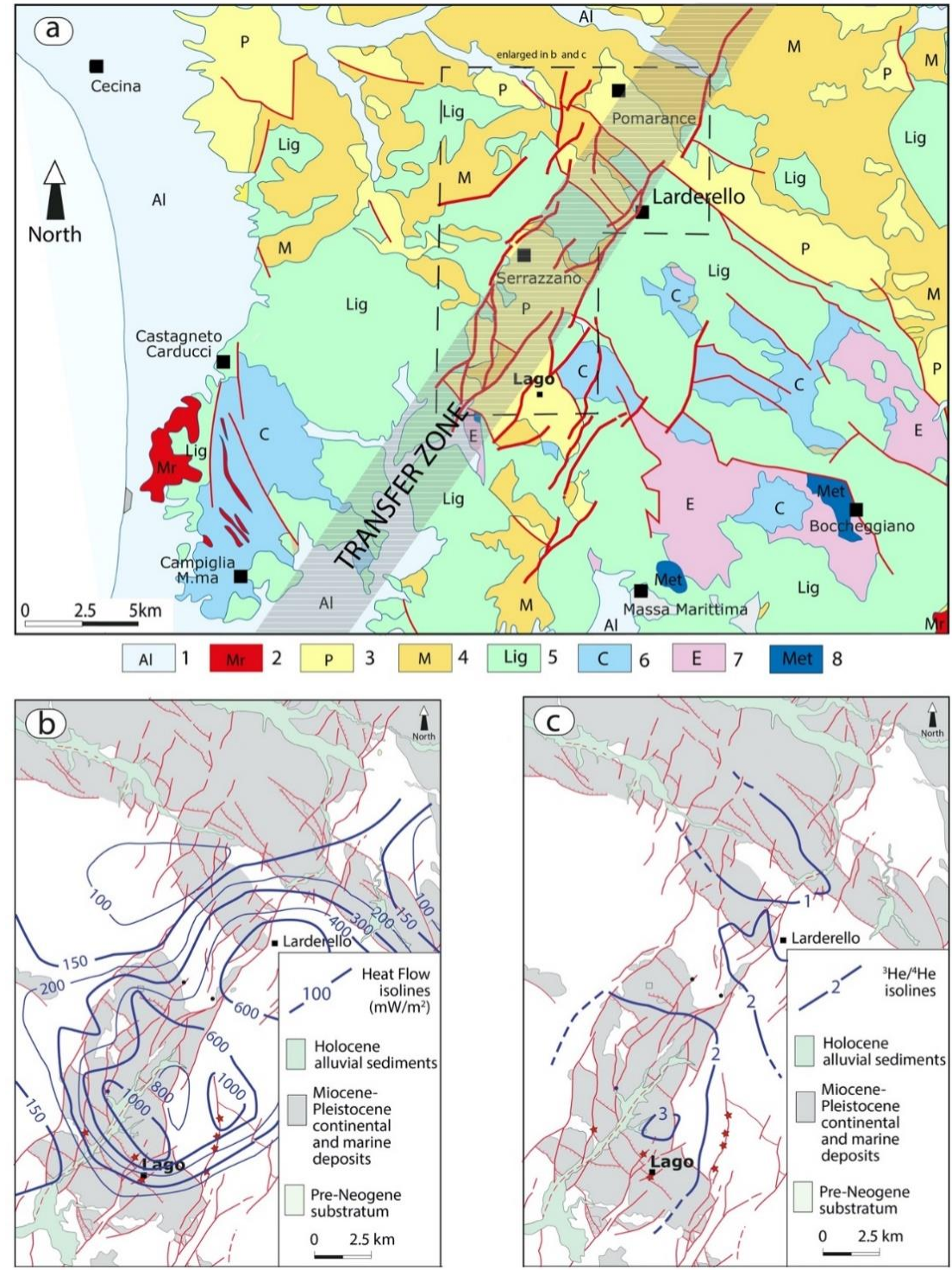

Figure 12. Larderello geothermal system: (a) Geological sketch map of Larderello and its surroundings. The transfer zone passing through the area is also indicated. Symbols: 1-Alluvial sediments (Holocene). 2-Magmatic rocks. (Pliocene-Pleistocene) Neogene deposits: 3-Marine deposits (Pliocene); 4-continental to marine deposits (Serravallian-Messinian). Ligurian Units: 5-Ophiolite and related sedimentary cover (Jurassic-Eocene) and carbonate-turbiditic succession (Eocene-Oligocene). Tuscan Units: 6-carbonate and terrigenous succession (Late Trias-Early Miocene); 7-evaporite (Late Trias); 8-metapelite and quartzite (Paleozoic-Late Trias). (b) contour lines indicating the heat flux in the study area: the highest values are located where the substratum of the Neogene sediments is deeper; (c) distribution of the ${ }^{3} \mathrm{He} /{ }^{4} \mathrm{He}$ ratio in the study area: the mantle contribution is highest where the substratum of the Neogene sediments is deeper (after Reference [29]). 
A major lithological element of similarity between Larderello and Elba, is derived by the occurrence of tourmaline in the micaschist, drilled at depth in the Larderello geothermal system [62,78]. Furthermore, comparably to Elba, the oblique-slip faults are also characterized by overprinted normal kinematics, thus indicating their role during reactivation of the pre-existing discontinuities [29]. This implies the interplay between stretching and uplift, determining a switch of the intermediate axis when, in turn, one of the two processes is prominent (Figure 13). Such a switch can, therefore, favor the upwelling of deep fluids and storage in later reservoir, here represented by the detachment level (late Trias evaporite) at the base of the continental sedimentary succession or by the normal fault damage zones where the intermediate axis (i.e., the direction of preferential flow) is close to be horizontal.

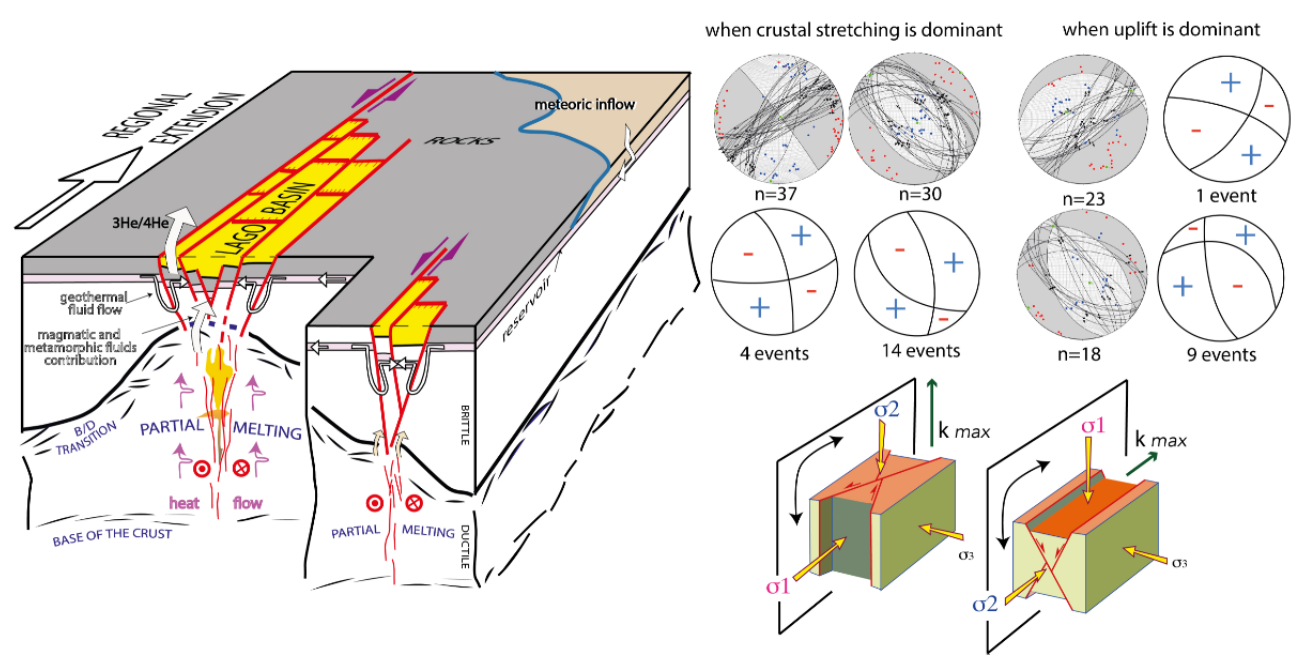

Figure 13. Conceptual model of the Larderello tectonic setting (after Reference [29]). Right: Geological sketch (not to scale) illustrating the tectonic context in which the Lago Basin is located. The Lago Basin is a pull-apart basin developed within the transfer zone affecting the geothermal area. The pull-apart crustal sector results more permeable, channeling deep geothermal fluids and magma at depth. Left: In the frame of extensional tectonics, kinematics of faults is controlled by crustal stretching or uplift. The stereonets show the comparison between the inversion of kinematic data from the field and local focal mechanisms. The variation of kinematics determines the switch of direction along which permeability is higher. The change of permeability direction through time enhances the effectivity of the geothermal system, permitting the up-flow of deep fluids and their lateral storage in structural traps hydraulically connected to the transfer zone.

\subsubsection{Elba Island vs. Larderello}

The comparison between the two systems indicates the validity of the proposed methodology in order to have data about the deep roots of an active geothermal systems. The role of the transfer zone, in channeling deep fluids, is well documented in Elba Island by the relationships between tourmaline and shear fractures. Similarly, a transfer zone is controlling the structural setting of the most productive part of the Larderello system. Finally, similar relations are documented also between the distribution of the mineralized Fe-oxides and -hydroxides minerals and fractures, suggesting that the system remained constant through the geological time. Presently, the same framework is confirmed by the stress analysis and fault setting in the active geothermal system. Furthermore, in both fossil and active systems, a lateral reservoir at the level of the Triassic rocks is documented, although completely crystallized in the Elba Island. Values of permeability and hydraulic conductivity estimated in the fossil system are then comparable with those presently measured in the active geothermal area in boreholes [51,70]. Concluding the methodology of comparing fossil and exhumed system is strengthen by the study of fossil systems, thus contributing to the construction of a robust predictive model of exploration. 


\subsection{Absence of Lateral Reservoir: Geitafell and Krafla Geothermal Systems}

Intrusive and effusive magmatic environments are normally characterized by absence of lateral reservoirs. This is a consequence of lithology, since porous lava levels are occasional and discontinuous in volcanic successions. In this context, Iceland is a good example of absence of lateral reservoir. Hence, permeability is connected to fractures, only. The three main factors favoring geothermal resources are all present in Iceland: (a) Iceland benefits of a diffuse high heat flux, since it is located above a mantle plume [79]; (b) active tectonic activity, combined with magmatic activity, determines and maintains permeability [80]; and (c) meteoric recharge, with minor contributes of magmatic fluids and sea water [81], is always efficient. Thus, the comparison between active and fossil system is finalized to the understanding of the deep roots of active systems, normally located at depths less than $2 \mathrm{~km}$ [82]. Iceland is an emergent $300 \times 500 \mathrm{~km}$ wide platform, of flood basalt and intrusive rocks. It is located at the divergent margins, separating the Eurasian and American plates, at the top of a mantle plume [83-85]. Due to the interaction between divergence and mantle plume, several rifts and two main transform zones (Figure 14), N-S and WSW-ENE respectively oriented, have been developing since Neogene [86-88]. Within rift zones, volcanism is associated with central volcanoes $[79,80,89]$ and fissure swarms, mainly parallel to the faults. Central volcanoes are often characterized by a caldera where geothermal circulation is enhanced, as the case of the active Krafla geothermal field [90]. Two main structural trends are regionally recognized in Iceland: (i) SSW-NNE striking normal faults and extensional fissures [91,92]; and (ii) WNW-ESE oriented transform zones [93]. Since the volcanic activity is directly connected to the crustal accretionary process at the divergent margins, central volcanoes have been progressively set apart from the main central rift. In this context the Geitafell volcano, located in the rift valley during late Miocene-Pliocene [79,94], has migrated southeastwards (Figure 14) and now represents a fossil, exhumed geothermal system, analogue of Krafla.

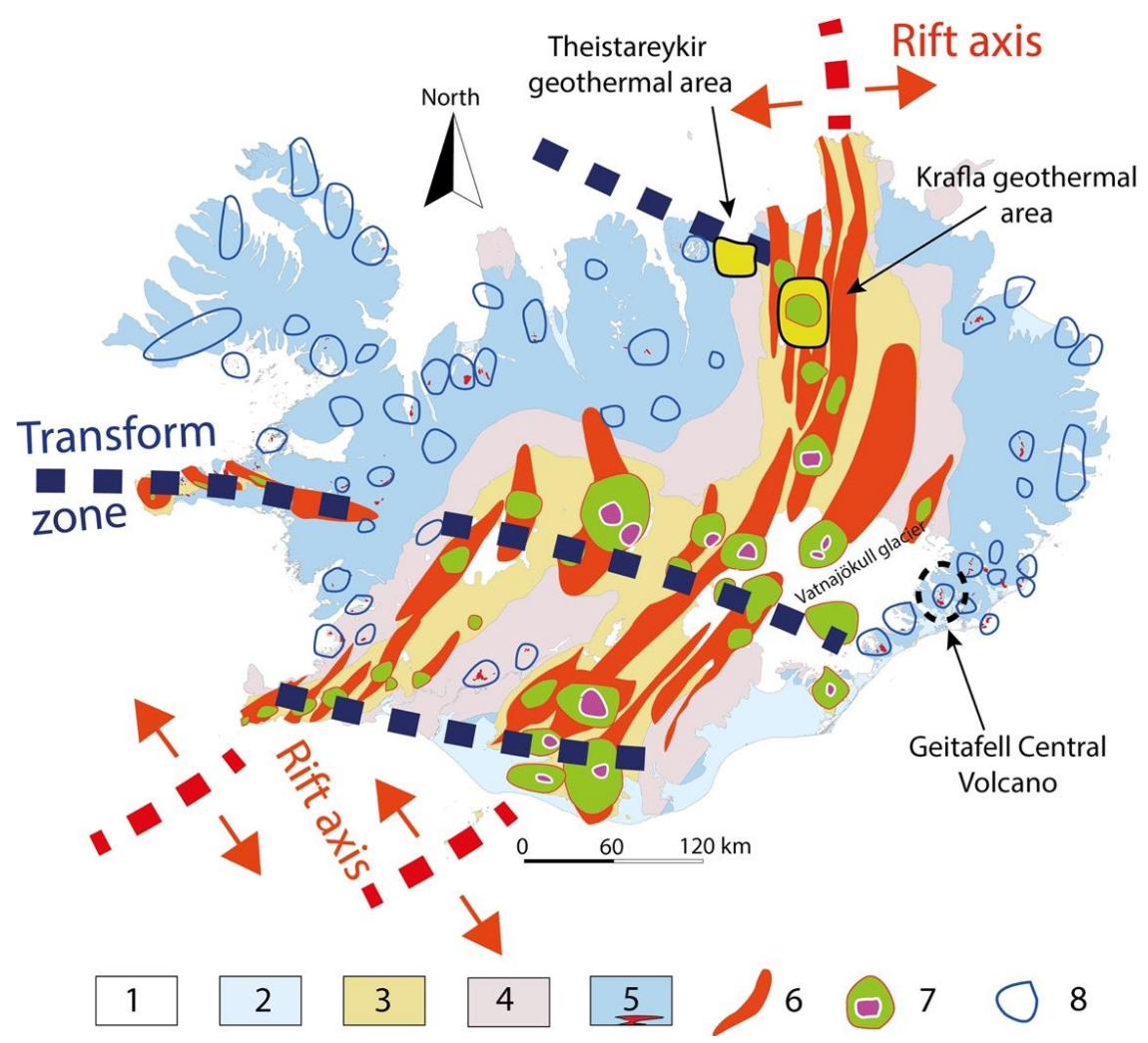

Figure 14. Tectonic sketch-map of Iceland (after Reference [86]). Symbols 1: glacier; 2-Holocene deposits; 3-Late Pleistocene deposits; 4-Tertiary basalt and magmatic intrusions; 5-fissure swarm; 6-active central volcano and its caldera; 7-fossil central volcano; 8-inactive central volcano. 


\subsubsection{Geitafell}

The Geitafell Neogene Central Volcano (sensu [95]) consists mostly of: basaltic lavas $(65 \%)$, hyaloclastites $(30 \%)$, and minor intermediate and silicic products $(5 \%)$ and gabbro dykes dipping toward the magma chamber [82], made up of gabbro, mainly [94]. Due to glacial erosion (Figure 15a), the upper portion of the Geitafell magma chamber is, at present, partly exposed [94].

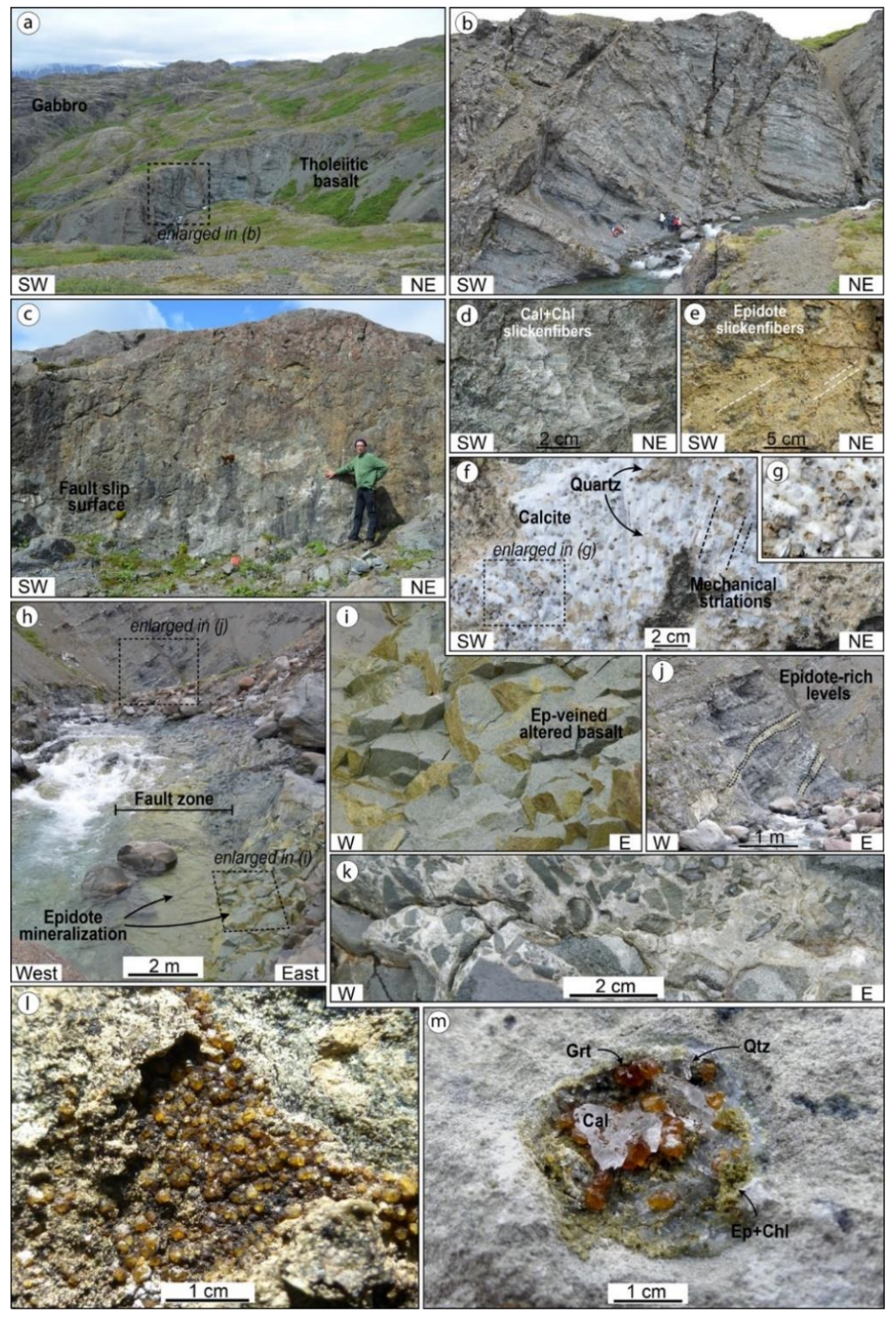

Figure 15. Photos of outcrops from the exhumed geothermal system of Geitafell (after Reference [13]): (a) panoramic view of the gabbro and host rocks; (b) panoramic view of a fault zone affecting the hosting rocks; (c) example a mineralized fault slip surface, in gabbro; (d-e) calcite, chlorite and epidote slickenfibers on slip surfaces with oblique-slip component, indicating syn-kinematic geothermal fluids circulation; $(\mathbf{f}-\mathbf{g})$ quartz and calcite mineralization associated to the subsequent (normal) movement of the fault; (h) panoramic view of a mineralized (epidote and calcite) fault zone; (i) detail of epidote-altered basalt; (j) epidote-rich levels of vesicular basalt hydraulically connected with the fault zone shown in (h); (k) detail of mineralized hydraulic breccia developed along the fault zone; (1) porous basalt lava can host garnet crystals aggregate when hydraulically connected to the channeling fault zone; $(\mathbf{m})$ detail of a vesicle characterizing basalt made up of hydrothermal minerals. Mineral abbreviation from Reference [70]. 
The interaction between magma cooling and meteoric fluids [96] resulted in the development of a zoned mineralogical assemblage, from contact metamorphism to hydrothermal system consisting of mineralized faults and related fractures (References [82,94]. Original permeability of the magmatic rocks is scarce (from $10^{-22}$ to $10^{-17} \mathrm{~m}^{2}$; Reference [97]) and limited to localized volumes of porous lavas. So, primary permeability is not sufficient to permit efficient geothermal fluid circulation at depth. Only brittle structures (Figure 15b) can promote fluid flow, creating preferential structural channels [98]. In the Geitafell fossil system, this is reflected by the development of hydrothermal vein networks (Figure 15c-k) and some mineral paragenesis [82,94], formed in limited porous levels (Figure 15 1,m).

The methodology of the study of the Geitafell exhumed system follows the already described approach: fieldwork mapping, fracture analysis by scan lines and scan boxes, fluid inclusions studies and finally, evaluation of the parameters describing permeability and properties of the fluids [13]. Fieldwork results indicate that the area is affected by two system of faults: (i) NNE-trending faults, with a mainly normal to oblique-slip kinematics; (ii) WNW-trending faults, mainly exhibiting left-lateral oblique-slip kinematics. This second system is explained as an expression of the transform zone interacting with the NNE- trending rift faults. The Geitafell volcano is, therefore, connected to the intersection between the two systems, highlighting the role of fault related permeability in developing vertical permeability and channeling deep fluids, even magmatic. In this view, a critical role is then played by the oblique slip faults (WNW-trending faults), characterized by an intermediate stress axis close to the vertical.

The fact that hydrothermal minerals are sealing fault zones (Figure 15), cutting across gabbro and host rocks, suggests that the distribution of the hydrothermal parageneses is controlled by fluid flow in fractures rather than conductive heat transfer from the magmatic source, as it is dominant in thermo-metamorphic aureoles.

Fluid inclusions were investigated in hydrothermal quartz and calcite collected in the field and from boreholes, the latter drilled into the contact aureole [13]. The main results indicate that the trapped paleo-fluids were characterized by temperature mainly between 255 and $320^{\circ} \mathrm{C}$, and that the fluid progressive cooled during a late evolution of the system down to $60-90^{\circ} \mathrm{C}$. Most inclusions trapped were under a hydrostatic pressure of 115 bars, although temporary pressure drop, likely related to fracture opening during tectonic activity, led to transient fluid boiling processes. Fluid salinity was generally low (from 0 to $1.5 \mathrm{wt}$ \% $\mathrm{NaCl}$ equivalent), indicating a dominant meteoric origin; however, rare fluid inclusions with higher salinity (up to $10.6 \mathrm{wt} \% \mathrm{NaCl}$ equivalent) also occur. The latter saline inclusions can be probably related to boiling process or to local input of magmatic derived fluid.

Once again, following the previously described approach, permeability of rocks $\left(\mathrm{k}=1.3 \times 10^{-14} \mathrm{~m}^{2}\right)$, was computed, resulting comparable with that one from the active geothermal system of Krafla [99,100]. Density, viscosity, and hydraulic conductivity were evaluated in an interval of fluid temperatures as resulting from analyses in suitable, sealed fractures (Figure 16).

\begin{tabular}{|c|c|c|c|c|c|c|c|}
\hline PALEO-FLUID TYPE & \multicolumn{2}{|c|}{$\begin{array}{l}\operatorname{VISCOSITY}(\eta) \\
\left(\mu \mathrm{Pa}^{*} \mathrm{~s}\right)\end{array}$} & \multicolumn{2}{|c|}{$\begin{array}{l}\operatorname{DENSITY}(\rho) \\
\left(\mathrm{kg} / \mathrm{m}^{3}\right)\end{array}$} & $\begin{array}{l}\text { PERMEABILITY }(k) \\
\left(\mathrm{m}^{2}\right)\end{array}$ & \multicolumn{2}{|c|}{$\begin{array}{l}\text { HYDRAULIC CONDUCTIVITY (K) } \\
\qquad(\mathrm{m} / \mathrm{s})\end{array}$} \\
\hline Low-temperature $\left(60-90^{\circ} \mathrm{C}\right)$ & $3.1 * 10^{-04}$ & $4.7^{*} 10^{-04}$ & 966 & 984 & $1.3^{*} 10^{-14}$ & $2.8^{*} 10^{-08}$ & $6.8 * 10^{-08}$ \\
\hline
\end{tabular}

Figure 16. Minimum and maximum values of fluid density and viscosity, and of permeability and hydraulic conductivity considering early, high-temperature, and late low-temperature paleo-fluids, as based on the parameters obtained by field and laboratory analyses (after Reference [13]). Low-temperature data derive from fluid inclusions in calcite, whereas high-temperature data are from fluid inclusions analyzed in quartz. Both quartz and calcite were collected in the field and can be considered as representative of the main hydrothermal mineralizations recognized in the study area. The asterisk indicates the multiplication sign. 
Thus, a conceptual model indicating circulation along fractures is envisaged (Figure 17).

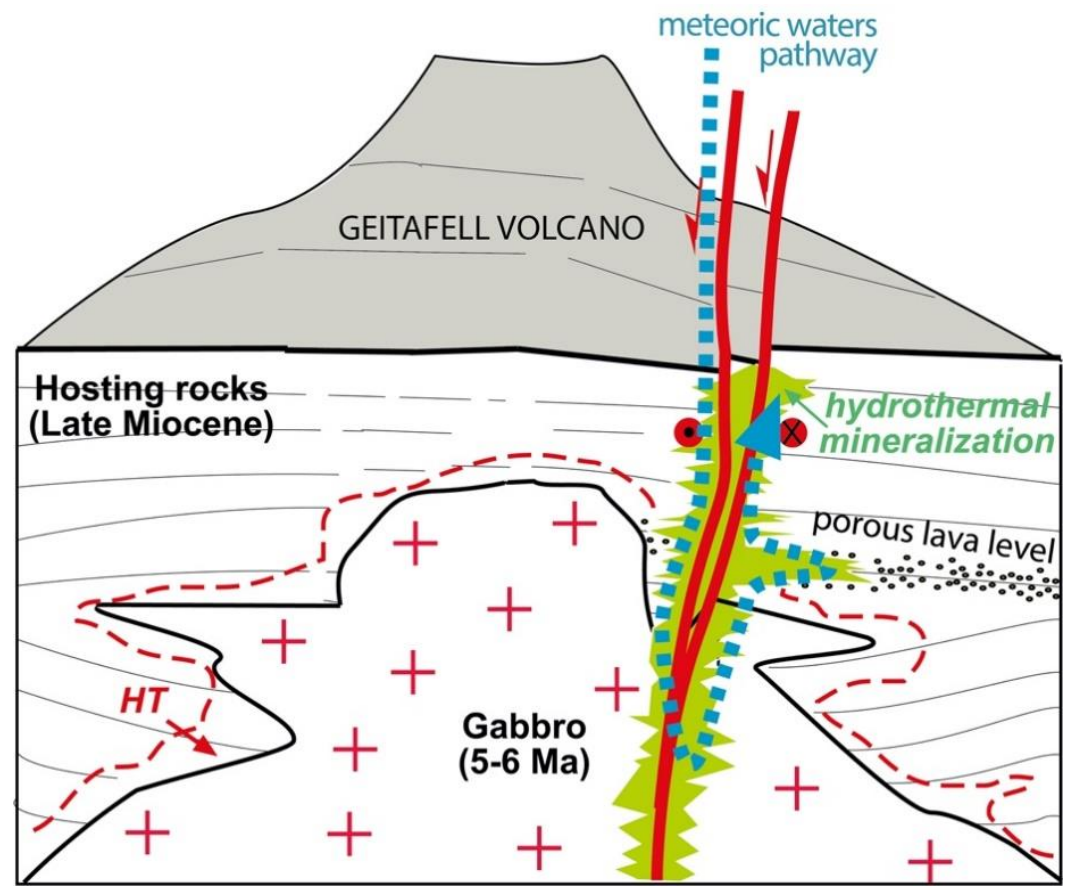

Figure 17. Conceptual model illustrating the relationships among fractures, meteoric fluid pathways and hydrothermal mineralization at the Geitafell study area (after Reference [13]).

\subsubsection{Krafla}

The Krafla volcano-geothermal area is characterized by a central caldera with active geothermal circulation (e.g., Reference [101] with references therein). Volcanism in the caldera is dominated by basaltic lava flows (from olivine tholeiite to Fe-rich tholeiite and basaltic andesite), although occasional silicic eruptions are also present [102]. A NNE-SSW trending fissure swarm dominantly crosses the Krafla volcanic area (e.g., Reference [103]). Boreholes down to about $2 \mathrm{~km}$ have revealed a substratum made up of basalt lava flows interlayered with hyaloclastite while, at deeper structural levels, dolerite and gabbro become dominant [101]. The study of seismic waves deriving from the earthquakes of the rift activity revealed a magma chamber at 3-7 km depth, in the mid-section of the caldera [104], although results from Reference [105] indicated a possible magma source at roughly $2.7 \mathrm{~km}$ depth, under the brittle-ductile boundary, in the production area [106].

Morphological and field data indicate that the area is affected by two system of faults [86,107-109], NNE-SSW to NNW-SSE and WSW-ENE oriented, respectively, with the latter interpreted as associated to transform shear zones. Due to the intense weathering and rheological properties of the volcanic deposits, kinematic indicators are scarce, the few indicating an oblique and normal component for the WSW-ENE and NNE-SSW to NNW-SSE oriented fault system, respectively [86].

At surface, the alignment of geothermal manifestations and fissured lava ridges forming fissure swarms, are considered as indicators of deep permeable structures [80]. This is also supported by the occurrence of silica sinter deposits, especially located at the intersection between the two structural trends (Figure 18), indicating a local increase of the permeability that permits to the geothermal fluids to be channeled without losing temperature during upflow [86]. At Krafla, significantly, the distribution of isotherms, earthquakes and the area under exploitation follow the transform shear zone orientation, rather than the rift-axis trend (Figure 19). In this view, the role of transform shear zones appear to be the most efficient to channel the upflow of deep fluids, suggesting that the 
geothermal system of Krafla is mostly linked to structures parallel to the main Húsavík transform fault zone (Figure 20).
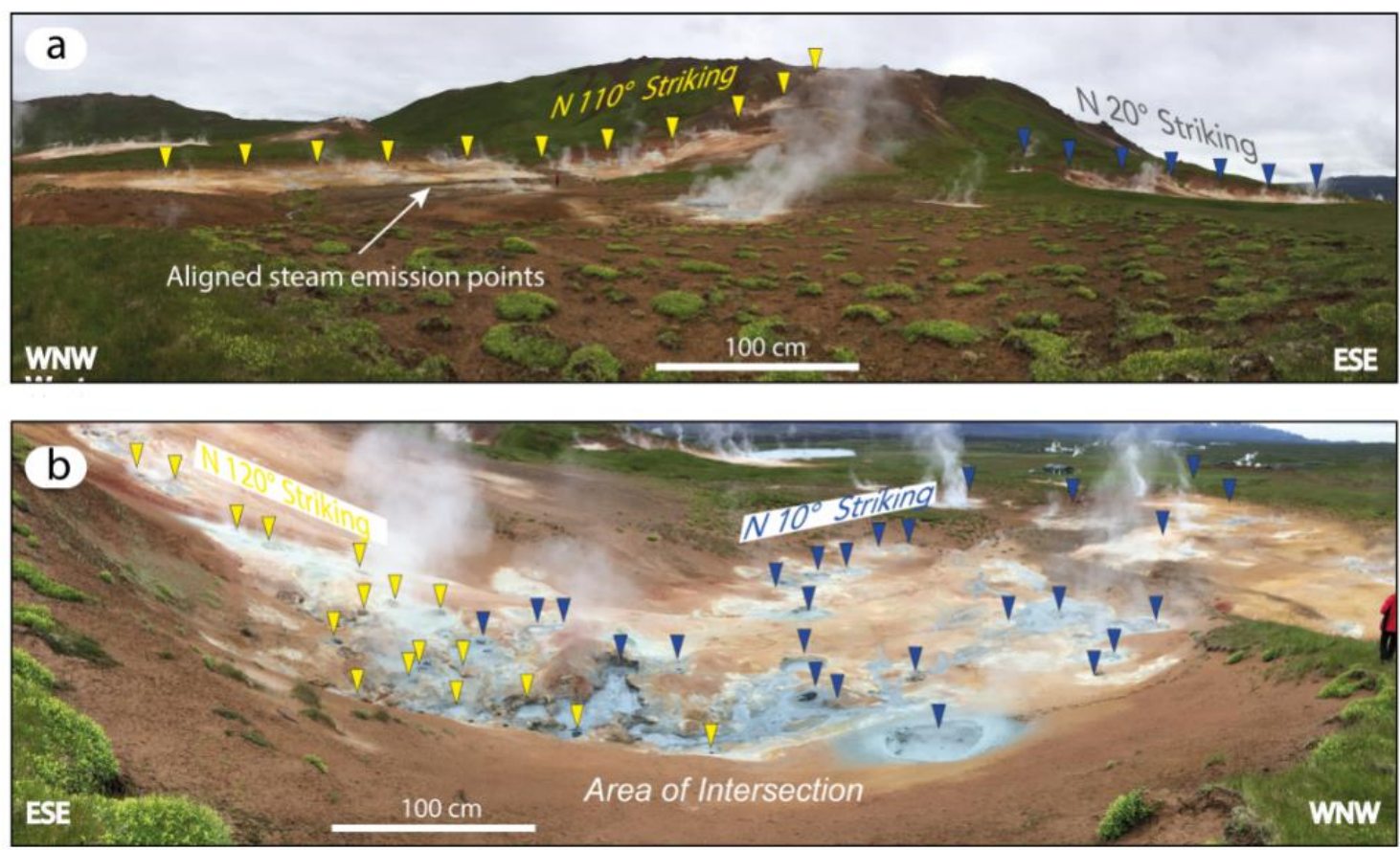

Figure 18. Examples of intersections between the two regional systems of Iceland (a) panoramic view of the steam emission points and relationships between the two main indicated trends; (b) geothermal manifestation at the intersection area between the two indicated fault trends; after Reference [86].


Figure 19. (a) Isotherms showing the distribution of temperature at Krafla; (b) distribution of epicenters in the geothermal area of Krafla. Their depth is between 1.8 and $2.4 \mathrm{~km}$. After Reference [86]. 


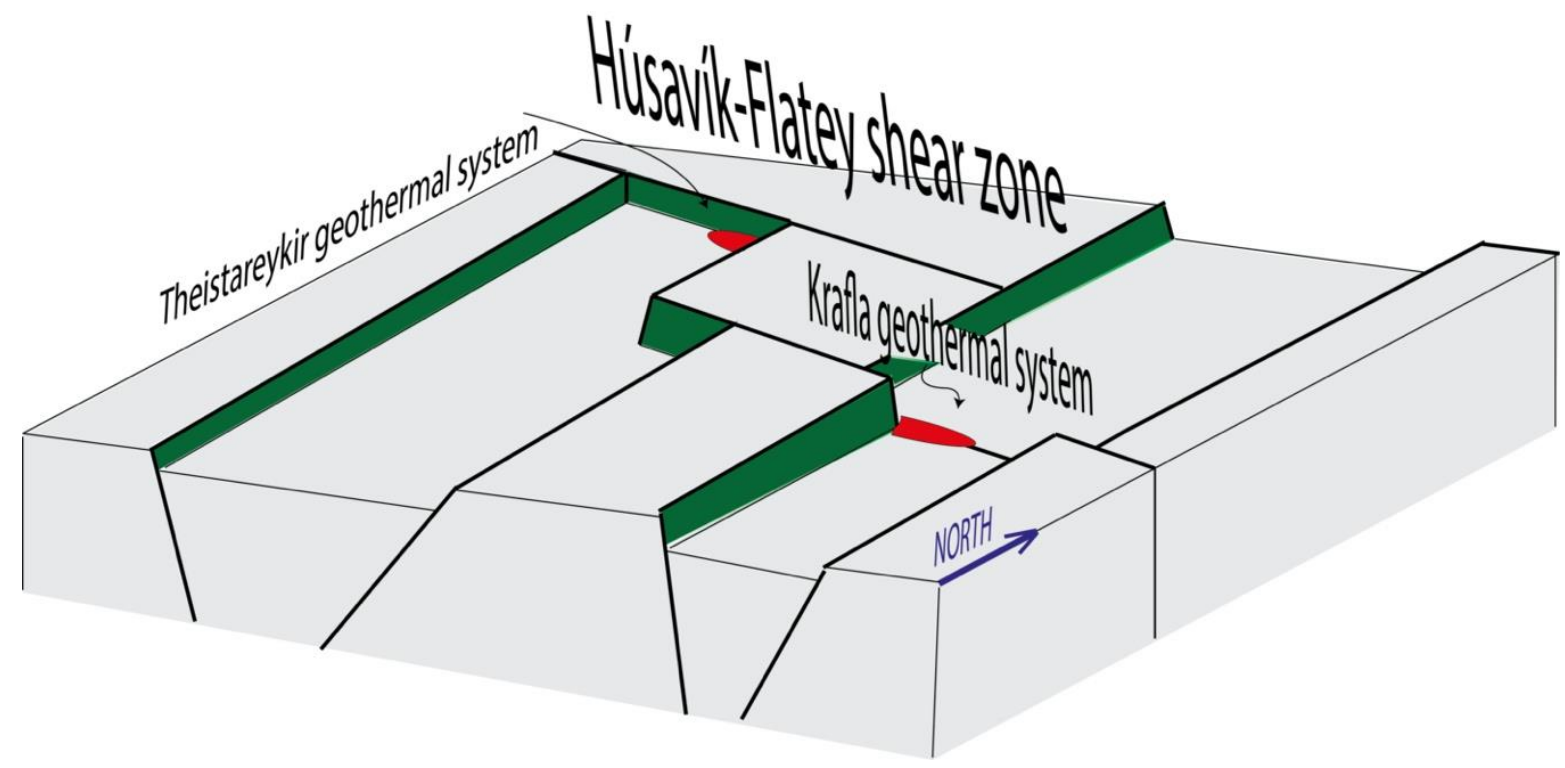

Figure 20. Conceptual structural model (not to scale) describing the relationships between geological structures and geothermal resources in the Krafla area, after Reference [86].

\subsubsection{Geitafell vs. Krafla}

The study of the fossil system demonstrated that permeability increased at the intersection between the two regional trends of fault systems, with emphasis on the role of the NW-trending faults in channeling deep fluids. This is the same evidence at Krafla, where thermal springs and silica sinter deposits are mostly localized at the intersection among faults. Moreover, at Krafla, the occurrence of a NW- trending brittle shear zone with fluids is marked by the distribution of earthquakes and increase of temperature. Finally, the field study of permeability and the analysis of paleo-fluids at Geitafell resulted a powerful method, when compared with the knowledge we have about the Krafla system. Once again, the methodology of studying fossil system in order to shed light on the deep roots of active system is proven and can provide key-indications for conceptual models on the relationships between geological structures and geothermal resources.

\section{Discussion and Conclusions}

The study of exhumed, analogue system is a common approach in the oil and gas exploration (e.g., References [110-112]) whereas it is quite recent in geothermal studies (e.g., References $[19,113])$. The study of fossil, analogue, geothermal systems significantly differs from the one dedicated to hydrocarbon since it benefits of the observation of a "crystallized condition", developed at depth and then intactly exhumed. This is in fact the case of the hydrothermal veins. Contrastingly, carbonate levels, hosting hydrocarbon at depth, when exhumed, are also affected by fractures developed during exhumation, thus making difficult to separately examine those fractures formed at the depth of interest.

Nevertheless, analysis of the hydrothermal veins might bring to an overestimation in term of permeability. The method is in fact based on measurements of the vein length and thickness, assuming that veins with the same mineralogical association were contemporaneously active. This is not the case for the shallower systems where banded veins can develop exhibiting repeated events of opening and mineral filling (e.g., References $[11,114])$. Nevertheless, for veins developed at the deeper structural levels, this simplification is also a consequence of the fact that hydrothermal veins are typified by comminution of mineral-filling fractures, hence indications about the evolution of the veins (as, for example, proposed by References [115-117]), are not recognizable, generally.

A mitigation of the $k$ value overestimation is, however, determined by the statistical approach which tends to highlight the most suitable value. Furthermore, it should be taken 
in account that large veins, such as the hydraulic breccias (burst veins in: Reference [117]) producing instantaneous, co-seismic veins [118], are not compatible with the laminar flow of the parallel plate model, thus being excluded by the database. Similarly, computations resulting in $k$ values $\geq 1 \times 10^{-12} \mathrm{~m}^{2}$ are excluded too, since not consistent with the assumptions of the parallel plate model. However, it is worth it to say that, although with limitations, the parallel plate model gives reliable results, being comparable with the permeability values measured in the active systems.

Hydraulic conductivity $(\mathrm{K})$ is evaluated simplifying the Darcy's low, since the movement of fluids is toward the Earth surface, hence the contribute of the hydraulic head and gravity cannot be stated. A range of $\mathrm{K}$ values can be reasonably suggested since it is influenced by pressure of fluids, variable time by time.

Another issue to be pointed out is the importance of the shear zones with a dominant oblique movement. In terms of channeling of deep fluids, these are the most favorable structures since their kinematics implies an almost vertical intermediate axis. When these structures interact with normal fault zones, then: (a) permeability locally increases, due to the interaction between two system of fractures; and (b) since the intermediate axis is almost horizontal in normal faults, lateral migration of fluids is favored. In our examples, these structural relations are significant both in the continental and oceanic crust environments, under extensional context. In conclusion, the presented methodological approach, based on integrated study of exhumed and active geothermal systems with field and laboratory methodologies, allows to better define conceptual models of the area under exploration. Thus, we encourage the study of fossil systems in order to shed light on the deep structures of the active geothermal systems, with benefit in the de-risking of failed drillings.

Author Contributions: D.L.: Conceptualization, Writing - original draft, review \& editing, Data curation, Investigation; A.B.: review \& editing, Data curation, Investigation; G.R.: review \& editing, Data curation, Investigation; M.Z.: review \& editing, Data curation, Investigation. All authors have read and agreed to the published version of the manuscript.

Funding: The research leading to these results has received funding from the European Community's Seventh Framework Program under grant agreement No. 608553 (Project IMAGE).

Institutional Review Board Statement: Not applicable.

Informed Consent Statement: Informed consent was obtained from all subjects involved in the study.

Acknowledgments: Two anonymous reviewers helped us to improve our original manuscript with their criticism.

Conflicts of Interest: The authors declare no conflict of interest.

\section{References}

1. Hanson, M.C.; Oze, C.; Horton, T.W. Identifying blind geothermal systems with soil CO2 surveys. Appl. Geochem. 2014, 50, 106-114. [CrossRef]

2. Chiodi, A.; Tassi, F.; Báez, W.; Filipovich, R.; Bustos, E.; Glok-Galli, M.; Suzaño, N.; Ahumada, M.F.; Viramonte, J.G.; Giordano, G.; et al. Preliminary conceptual model of the Cerro Blanco caldera-hosted geothermal system (Southern Puna, Argentina): Inferences from geochemical investigations. J. S. Am. Earth Sci. 2019, 94, 102213. [CrossRef]

3. Santilano, A.; Donato, A.; Galgaro, A.; Montanari, D.; Menghini, A.; Viezzoli, A.; di Sipio, E.; Destro, E.; Manzella, A. An integrated 3D approach to assess the geothermal heat-exchange potential: The case study of western Sicily (southern Italy). Renew. Energy 2016, 97, 611-624. [CrossRef]

4. Millett, J.M.; Planke, S.; Kästner, F.; Blischke, A.; Hersir, G.P.; Halldórsdóttir, S.; Flóvenz, Ó.G.; Árnadóttir, S.; Helgadóttir, H.M.; Vakulenko, S.; et al. Sub-surface geology and velocity structure of the Krafla high temperature geothermal field, Iceland: Integrated ditch cuttings, wireline and zero offset vertical seismic profile analysis. J. Volcanol. Geotherm. Res. 2020, $391,106342$. [CrossRef]

5. Pavez, M.; Schill, E.; Held, S.; Díaz, D.; Kohl, T. Visualizing preferential magmatic and geothermal fluid pathways via electric conductivity at Villarrica Volcano, S-Chile. J. Volcanol. Geotherm. Res. 2020, 400, 106913. [CrossRef]

6. Rowland, J.V.; Sibson, R.H. Structural controls on hydrothermal flowing a segmented rift system, Taupo Volcanic Zone, New Zealand. Geofluids 2004, 4, 259-283. [CrossRef] 
7. Faulds, J.E.; Coolbaugh, M.F.; Hinz, N.H.; Cashman, P.H.; Kratt, C.; Dering, G.; Edwards, J.; Mayhew, B.; McLachlan, H. Assessment of favorable structural settings of geothermal systems in the Great Basin, western USA. Geotherm. Resour. Counc. Trans. 2011, 35, 777-784.

8. Olvera-García, E.; Garduño-Monroy, V.H.; Liotta, D.; Brogi, A.; Bermejo-Santoyo, G.; Guevara-Alday, J.A. Neogene-Quaternary normal and transfer faults controlling deep-seated geothermal systems: The case of San Agustín del Maíz (central Trans-Mexican Volcanic Belt, México). Geothermics 2020, 86, 101791. [CrossRef]

9. Calcagno, P.; Evanno, G.; Trumpy, E.; Gutiérrez-Negrín, L.C.; Macías, J.L.; Carrasco-Núñez, G.; Liotta, D. Preliminary 3-D geological models of Los Humeros and Acoculco geothermal fields (Mexico)—H2020 GEMex Project. Adv. Geosci. 2018, 45, 321-333. [CrossRef]

10. Békési, E.; Struijk, M.; Bonté, D.; Veldkamp, H.; Limberger, J.; Fokker, P.A.; Vrijlandt, M.; van Wees, J.D. An updated geothermal model of the Dutch subsurface based on inversion of temperature data. Geothermics 2020, 88, 101880. [CrossRef]

11. Liotta, D.; Ruggieri, G.; Brogi, A.; Fulignati, P.; Dini, A.; Nardini, I. Migration of geothermal fluids in extensional terrains: The ore deposits of the Boccheggiano-Montieri area (southern Tuscany, Italy). Int. J. Earth Sci. 2010, 99, 623. [CrossRef]

12. Zucchi, M.; Brogi, A.; Liotta, D.; Rimondi, V.; Ruggieri, G.; Montegrossi, G.; Caggianelli, A.; Dini, A. Permeability and hydraulic conductivity of faulted micaschist in the eastern Elba Island exhumed geothermal system (Tyrrhenian sea, Italy): Insights from Cala Stagnone. Geothermics 2017, 70, 125-145. [CrossRef]

13. Liotta, D.; Brogi, A.; Ruggieri, G.; Rimondi, V.; Zucchi, M.; Helgadóttir, H.M.; Montegrossi, G.; Friðleifsson, G.Ó. Fracture analysis, hydrothermal mineralization and fluid pathways in the Neogene Geitafell central volcano: Insights for the Krafla active geothermal system, Iceland. J. Volcanol. Geotherm. Res. 2020, 391, 23. [CrossRef]

14. Zucchi, M. Faults controlling geothermal fluid flow in low permeability rock volumes: An example from the exhumed geothermal system of eastern Elba Island (northern Tyrrhenian Sea, Italy). Geothermics 2020, 85, 101765. [CrossRef]

15. Caine, S.J.; Evans, J.P.; Forster, C.B. Fault zone architecture and permeability structure. Geology 1996, 24, 1025-1028. [CrossRef]

16. Sibson, R.H. Fluid involvement in normal faulting. J. Geodyn. 2000, 29, 469-499. [CrossRef]

17. Curewitz, D.; Karson, J.A. Structural setting of hydro-thermal overflow: Fracture permeability maintained by fault propagation and interaction. J. Volcanol. Geotherm. Res. 1997, 79, 149-168. [CrossRef]

18. Barbier, E. Geothermal energy and current status: An overview. Renew. Sustain. Energy Rev. 2002, 6, 3-65. [CrossRef]

19. Brogi, A.; Alçiçek, M.C.; Yalçıner, C.C.; Capezzuoli, E.; Liotta, D.; Meccheri, M.; Rimondi, V.; Ruggieri, G.; Gandin, A.; Boschi, C.; et al. Hydrothermal fluids circulation and travertine de-position in an active tectonic setting: Insights from the Kamara geothermal area (western Anatolia, Turkey). Tectonophysics 2016, 680, 211-232. [CrossRef]

20. Chafetz, H.S.; Folk, R.L. Travertines: Depositional morphology and the bacterially constructed constituents. J. Sedim. Petrol. 1984, 54, 289-316.

21. Ford, T.D.; Pedley, H.M. A review of travertine deposits of the world. Earth Sci. Rev. 1996, 41, 117-175. [CrossRef]

22. Hancock, P.L.; Chalmers, R.M.L.; Altunel, E.; Çakır, Z. Travitonics: Using travertines in active fault studies. J. Struct. Geol. 1999, 21, 903-916. [CrossRef]

23. Capezzuoli, E.; Gandin, A.; Pedley, H.M. Decoding tufa and travertine (freshwater carbonates) in the sedimentary record: The state of the art. Sedimentology 2014, 61, 1-21. [CrossRef]

24. Brogi, A.; Capezzuoli, E.; Buracchi, E.; Branca, M. Tectonic control on travertine and calcareous tufa deposition in a lowtemperature geothermal system (Sarteano, Central Italy). J. Geol. Soc. (Lond.) 2012, 169, 461-476. [CrossRef]

25. Brogi, A.; Liotta, D.; Capezzuoli, E.; Matera, P.F.; Kele, S.; Soligo, M.; Tuccimei, P.; Ruggieri, G.; Yu, T.L.; Shen, C.C.; et al. Travertine deposits constraining transfer zone neotectonics in geothermal areas: An example from the inner Northern Apennines (Bagno Vignoni-Val d'Orcia area, Italy). Geothermics 2020, 85, 101763. [CrossRef]

26. Uysal, I.T.; Feng, Y.; Zhao, J.X.; Altunel, E.; Weatherley, D.; Karabacak, V.; Cengiz, O.; Golding, S.D.; Lawrence, M.G.; Collerson, K.D. U-series dating and geochemical tracing of late Quaternary travertine in co-seismic fissures. Earth Planet. Sci. Lett. 2007, 257, 450-462. [CrossRef]

27. Brogi, A.; Alçiçek, M.C.; Liotta, D.; Capezzuoli, E.; Zucchi, M.; Matera, P.F. Step-over fault zones controlling geothermal fluid-flow and travertine formation (Denizli Basin, Turkey). Geothermics 2021, 89, 101941. [CrossRef]

28. Angelier, J. Determination of the mean principal directions of stresses for a given fault population. Tectonophysics 1979, 56, 17-26. [CrossRef]

29. Liotta, D.; Brogi, A. Pliocene-Quaternary fault kinematics in the Larderello geothermal area (Italy): Insights for the interpretation of the present stress field. Geothermics 2020, 83, 101714. [CrossRef]

30. Faulkner, D.R.; Armitage, P.J. The effect of tectonic environment on permeability development around faults and in the brittle crust. Earth Planet. Sci. Lett. 2013, 375, 71-77. [CrossRef]

31. Liotta, D.; Brogi, A.; Meccheri, M.; Dini, A.; Bianco, C.; Ruggieri, G. Coexistence of low-angle normal and high-angle strike- to oblique-slip faults during late Miocene mineralization in eastern Elba Island (Italy). Tectonophysics 2015, 660, 25. [CrossRef]

32. Olvera-García, E.; Bianco, C.; Garduño-Monroy, V.H.; Brogi, A.; Liotta, D.; Wheeler, W.; Gómez-Alvarez, F.; Najera-Blas, S.; Jiménez-Haro, A.; Guevara-Alday, J.A.; et al. Geological map of Las Minas: An example of an exhumed geothermal system (Eastern Trans- Mexican Volcanic Belt). J. Maps 2020, 16, 918-926. [CrossRef]

33. Gale, J.E. Assessing the permeability characteristics of fractured rock. Geol. Soc. Am. Spec. Pap. 1982, 189, $163-182$. 
34. Nicholl, M.J.; Rajaram, H.; Glass, R.J.; Detwiler, R. Saturated flow in a single fracture: Evaluation of the Reynolds equation in measured aperture fields. Water Resour. Res. 1999, 35, 3361-3373. [CrossRef]

35. Zimmerman, R.W.; Bodvarsson, G.S. Hydraulic conductivity of rock fractures. Transp. Porous Media 1996, 23, 1-30. [CrossRef]

36. Leung, C.T.O.; Zimmerman, R.W. Estimating the hydraulic conductivity of two dimensional fracture networks using network geometric properties. Transp. Porous Media 2012, 93, 777-797. [CrossRef]

37. Roedder, E. Fluid inclusions. Rev. Mineral. 1984, 12, 644.

38. Shepherd, T.J.; Rankin, A.H.; Alderton, D.H.M. A Practical Guide to Fluid Inclusion Studies; Blackie and Son Ltd.: Glasgow, Scotland, 1985; p. 239.

39. Goldstein, R.H.; Reynolds, T.J. Systematics of Fluid Inclusions in Diagenetic Minerals. SEPM Soc. Sediment. Geol. 1994, $31,199$.

40. Bodnar, R.J. Introduction to Fluid Inclusions. In Fluid Inclusions: Analysis and Interpretation; Samson, I., Anderson, A., Marshall, D., Eds.; Mineralogical Association of Canada: Quebec City, QC, Canada, 2003; Volume 32, pp. 1-8.

41. Goldstein, R.H. Petrographic analysis of fluid inclusions. In Fluid Inclusions: Analysis and Interpretation, Short Course; Samson, I., Anderson, A., Marshall, D., Eds.; Mineralogical Association of Canada: Ottawa, ON, Canada, 2003; Volume 32, pp. 9-53.

42. Hurai, M.; Huraiovà, M.; Slobodnik, M.; Thomas, R. Geofluids: Developments in Microthermometry, Spectroscopy, Thermodynamics, and Stable Isotopes; Elsevier: Amsterdam, The Netherlands, 2015; p. 485.

43. Bodnar, R. Introduction to Aqueous Fluid Systems. In Fluid Inclusions: Analysis and Interpretatio; Samson, I., Anderson, A., Marshall, D., Eds.; Mineralogical Association of Canada: Quebec City, QC, Canada, 2003; Volume 32, pp. 81-99.

44. Bakker, R.J. AqSo_NaCl: Computer program to calculate p-T-V-x properties in the $\mathrm{H} 2 \mathrm{O}-\mathrm{NaCl}$ fluid system applied to fluid inclusion research and pore fluid calculation. Computer Geosciences. Comput. Geosci. 2018, 115, 122-133. [CrossRef]

45. Driesner, T. The System H2O-NaCl. Part II. Correlations for molar volume, enthalpy, and isobaric heat capacity from 0 to 1000 ${ }^{\circ} \mathrm{C}, 1$ to 5000 bar, and 0 to $1 \mathrm{XNaCl}$. Geochim. Cosmochim. Acta 2007, 71, 4902-4919. [CrossRef]

46. Driesner, T.; Heinrich, C.A. The system H2O-NaCl. Part I. Correlation formulae for phase relations in pressure-temperaturecomposition space from 0 to $1000{ }^{\circ} \mathrm{C}, 1$ to 5000 bar, and 0 to $1 \mathrm{XNaCl}$. Geochim. Cosmochim. Acta 2007, 71, 4880-4901. [CrossRef]

47. Dubacq, B.; Bickle, M.J.; Evans, K.A. An activity model for phase equilibria in the H2O-CO2-NaCl system. Geochim. Cosmochim. Acta 2013, 110, 229-252. [CrossRef]

48. Mao, S.; Duan, Z. The Viscosity of Aqueous Alkali-Chloride Solutions up to $623 \mathrm{~K}, 1.000$ bar, and High Ionic Strength. Int. J. Thermophys. 2009, 30, 1510-1523. [CrossRef]

49. Gola, G.; Bertini, G.; Bonini, M.; Botteghi, S.; Brogi, A.; de Franco, R.; Dini, A.; Donato, A.; Gianelli, G.; Liotta, D.; et al. Data integration and conceptual modelling of the Larderello geothermal area, Italy. Energy Procedia 2017, 125, 300-309. [CrossRef]

50. Lelli, M.; Kretzschmar, T.G.; Cabassi, J.; Doveri, M.; Sanchez-Avila, J.I.; Gherardi, F.; Magro, G.; Norelli, F. Fluid geochemistry of the Los Humeros geothermal field (LHGF-Puebla, Mexico): New constraints for the conceptual model. Geothermics 2021, 90, 101983. [CrossRef]

51. Romagnoli, P.; Arias, A.; Barelli, A.; Cei, M.; Casini, M. An updated numerical model of the Larderello-Travale geothermal system. Italy. Geothermics 2010, 39, 292-313. [CrossRef]

52. Ratouis, T.M.P.; O'Sullivan, M.J.; O'Sullivan, J.P. A Numerical model of Rotorua Geothermal Field. Geothermics 2016, 60, 105-125. [CrossRef]

53. Molli, G. Northern Apennine-Corsica orogenic system: An updated overview. Geol. Soc. Lond. Spec. Publ. 2008, 298, 413-442. [CrossRef]

54. Barchi, M.R. The Neogene-Quaternary Evolution of the Northern Apennines: Crustal Structure, Style of Deformation and Seismicity. J. Virtual Explor. 2010, 36, 220. [CrossRef]

55. Serri, G.; Innocenti, F.; Manetti, P. Geochemical and petrological evidence of the subduction of delaminated Adriatic continental lithosphere in the genesis of the Neogene-Quaternary magmatism of central Italy. Tectonophysics 1993, 223, 117-147. [CrossRef]

56. Tanelli, G. Mineralizzazioni metallifere e minerogenesi della Toscana. Mem. Soc. Geol. Ital. 1983, 25, 91-109.

57. Minissale, A.; Magro, G.; Martinelli, G.; Vaselli, O.; Tassi, G.F. Fluid geochemical transect in the Northern Apennines (centralnorthern Italy): Fluid genesis and migration and tectonic implications. Tectonophysics 2000, 319, 199-222. [CrossRef]

58. Dini, A.; Gianelli, G.; Puxeddu, M.; Ruggieri, G. Origin and evolution of Pliocene-Pleistocene granites from the Larderello geothermal field (Tuscan Magmatic Province, Italy). Lithos 2005, 81, 1-31. [CrossRef]

59. Dini, A.; Westerman, D.S.; Innocenti, F.; Rocchi, S. Magma emplacement in a transfer zone: The Miocene mafic Orano dyke swarm of Elba Island, Tuscany, Italy. Geol. Soc. Lond. Spec. Publ. 2008, 302, 131-148. [CrossRef]

60. Carmignani, L.; Decandia, F.A.; Fantozzi, P.L.; Lazzarotto, A.; Liotta, D.; Meccheri, M. Tertiary extensional tectonics in Tuscany (northern Apennines, Italy). Tectonophysics 1994, 238, 295-315. [CrossRef]

61. Decandia, F.A.; Lazzarotto, A.; Liotta, D.; Cernobori, L.; Nicolich, R. The CROP03 traverse: Insights on post-collisional evolution of northern Apennines. Mem. Soc. Geol. Ital. 1998, 52, 427-439.

62. Pandeli, E.; Gianelli, G.; Puxeddu, M.; Elter, F. The paleozoic basement of the northern Apennines: Stratigraphy, tectonometamorphic evolution and alpine hydrothermal processes. Mem. Soc. Geol. Ital. 1994, 48, 627-654.

63. Gagnevin, D.; Daly, J.S.; Horstwood, M.S.A.; Whitehouse, M.J. In-situ zircon U-Pb, oxygen and hafnium isotopic evidence for magma mixing and mantle metasomatism in the Tuscan Magmatic Province. Italy. Earth Planet. Sci. Lett. 2011, 305, 45-56. [CrossRef] 
64. Foley, l.E.; Toksoz, M.N.; Batini, F. Inversion of teleseismic traveltime residuals for velocity structure in the Larderello geothermal field. Italy. Geophys. Res. Lett. 1992, 19, 5-8. [CrossRef]

65. Viti, C.; Brogi, A.; Liotta, D.; Mugnaioli, E.; Spiess, R.; Dini, A.; Zucchi, M.; Vannuccini, G. Seismic slip recorded in tourmaline fault mirrors from Elba Island (Italy). J. Struct. Geol. 2016, 86, 1-12. [CrossRef]

66. Zucchi, M. Fractures and Mineralizing Fluid Paths in the Eastern Elba Island Exhumed Geothermal System (Italy). Ph.D. Thesis, University of Bari, Bari BA, Italy, 2017; p. 190.

67. Dini, A.; Mazzarini, F.; Musumeci, G.; Rocchi, S. Multiple hydro-fracturing by boron-rich fluids in the Late Miocene contact aureole of eastern Elba Island (Tuscany, Italy). Terra Nova 2008, 20, 318-326. [CrossRef]

68. Orlando, A.; Ruggieri, G.; Chiarantini, L.; Montegrossi, G.; Rimondi, V. Experimental Investigation of Biotite-Rich Schist Reacting with B-Bearing Fluids at Upper Crustal Conditions and Correlated Tourmaline Formation. Minerals 2017, 7, 155. [CrossRef]

69. Cappetti, G.; Parisi, L.; Ridolfi, A.; Stefani, G. Fifteen Years of Reinjection in the Larderello-Valle Secolo Area: Analysis of the Production Data. In Proceedings of the May 18th Proceedings World Geothermal Congress WGC95, Florence, Italy, 18-31 May 1995; Volume 3, pp. 1797-2000.

70. Kretz, R. Symbols for rock-forming minerals. Am. Mineral. 1983, 68, 277-279.

71. Duranti, S.; Palmeri, R.; Pertusati, P.C.; Ricci, C.A. Geological evolution andme- tamorphic petrology of the basal sequence of eastern Elba (complex II). Acta Vulcanol. 1992, 2, 213-229.

72. Tanelli, G.; Benvenuti, M.; Costagliola, P.; Dini, A.; Lattanzi, P.; Maineri, C.; Macaro, I.; Ruggieri, G. The iron mineral deposits of Elba Island: State of the art. Ofioliti 2001, 26, 239-248.

73. Deschamps, Y.; Dagallier, G.; MAcaudière, J.; Marignac, C.; Moine, B.; Saupé, F. Le gisement de pyrite-hématite de Valle Giove (Rio Marina, Ile d'Elbe, Italie), Partie Schweiz. Mineral. Petrogr. Mitt. 1983, 63, 301-327.

74. Batini, F.; Brogi, A.; Lazzarotto, A.; Liotta, D. Geological features of Larderello-Travale and Mt. Amiata geothermal areas (southern Tuscany, Italy). Episodes 2003, 26, 239-244. [CrossRef] [PubMed]

75. Cameli, G.M.; Dini, I.; Liotta, D. Upper crustal structure of the Larderello geothermal field as a feature of post-collisional extensional tectonics (southern Tuscany, Italy). Tectonophysics 1993, 224, 413-423. [CrossRef]

76. Della-Vedova, B.; Bellani, S.; Pellis, G.; Squarci, P. Deep Temperatures and Surface Heat Flow Distribution. In Anatomy of An. Orogen: The Apennines and Adjacent Mediterranean Basins; Vai, G.B., Martini, I.P., Eds.; Kluwer Academic Publishers: Amsterdam, The Netherlands, 2001; pp. 65-76.

77. Magro, G.; Ruggieri, G.; Gianelli, G.; Bellani, S.; Scandiffio, G. Helium isotopes in paleofluids and present-day fluids of the Larderello geothermal field: Constraints on the heat source. J. Geophys. Res. 2003, 108, B1. [CrossRef]

78. Bertini, G.; Gianelli, G.; Pandeli, E.; Puxeddu, M. Distribution of hydrothermal minerals in the Larderello-Travale and Mt. Amiata geothermal fields (Italy). Geotherm. Res. Counc. Trans. 1985, 9, 261-266.

79. Saemundsson, K. Outline of the geology of Iceland. Jökull 1979, 29, 7-28.

80. Tentler, T.; Temperley, S. Magmatic fissures and their systems in Iceland: A tectonomagmatic model. Tectonics 2007, 26, TC5019. [CrossRef]

81. Arnórsson, S.; Axelsson, G.; Sremundsson, K. Geothermal systems in Iceland. Jökull 2008, 58, $269-305$.

82. Burchardt, S.; Guðmundsson, Á. The Infrastructure of Geitafell Volcano, Southeast Iceland. In Studies in Volcanology: The Legacy of George Walker; Geological Society of London: London, UK, 2009; Volume 2, pp. 349-370.

83. Wolfe, C.J.; Bjarnason, I.T.; Van Decar, J.C.; Solomon, S.C. Seismic structure of the Iceland mantle plume. Nature 1997, 385, $245-247$. [CrossRef]

84. Einarsson, P. Structure and evolution of the Iceland hotspot. Dtsch. Geophys. Ges. Mitt. 2001, 1, 11-14.

85. Bjarnason, I.T. An Iceland hotspot saga. Jökull 2008, 58, 3-16.

86. Liotta, D.; Brogi, A.; Árnadóttir, S.; Ágústsson, K.; Thorsteinsdóttir, U. Field evidence of the interplay between rift and transform structures in the Krafla geothermal area, N-Iceland. Geothermics 2021, 91, 102039. [CrossRef]

87. Jakobsdóttir, S. Seismicity in Iceland: 1994. Jökull 2008, 56, 75-100.

88. Angelier, J.; Bergerat, F.; Stefansson, R.; Bellou, M. Seismotectonics of a newly formed transform zone near a hotspot: Earthquake mechanisms and regional stress in the South Iceland Seismic Zone. Tectonophysics 2008, 447, 95-116. [CrossRef]

89. Einarsson, P. Earthquakes and present-day tectonism in Iceland. Tectonophysics 1991, 189, 261-279. [CrossRef]

90. Mortensen, A.K.; Grönvold, K.; Gudmunsson, Á.; Steingrímsson, B.; Egilson, T. Quenched Silicic Glass from Well KJ-39 in Krafla, North-Eastern Iceland. In Proceedings of the World Geothermal Congress 2010, Bali, Indonesia, 25-29 April 2010; pp. 1-6.

91. Grant, J.V.; Kattenhorn, S.A. Evolution of vertical faults at an extensional plate boundary, southwest Iceland. J. Struct. Geol. 2004, 26, 537-557. [CrossRef]

92. Tentler, T.; Mazzoli, S. Architecture of normal faults in the rift zone of central north Iceland. J. Struct. Geol. 2005, 27, 1721-1739. [CrossRef]

93. Guðmundsson, Á. Ocean-ridge discontinuities in Iceland. Geol. Soc. Lond. 1995, 152, 1011-1015. [CrossRef]

94. Friðleifsson, G.Ó. Mineralogical evolution of a hydrothermal system. Geotherm. Resour. Counc. Trans. 1983, 7, 147-152.

95. Thordarson, T.; Larsen, G. Volcanism in Iceland in historical time: Volcano types, eruption styles and eruptive history. J. Geodyn. 2007, 43, 118-152. [CrossRef]

96. Pope, E.C.; Bird, D.K.; Arnórsson, S. Stable isotopes of hydrothermal minerals as tracers for geothermal fluids in Iceland. Geothermics 2014, 49, 99-110. [CrossRef] 
97. Fisher, A.T. Permeability within basaltic oceanic crust. Rev. Geophys. 1998, 36, 143-182. [CrossRef]

98. Arnórsson, S. Geothermal systems in Iceland: Structure and conceptual models-I. High-temperature areas. Geothermics 1995, 24, 561-602. [CrossRef]

99. Axelsson, G.; Egilson, T.; Gylfadóttir, S.S. Modelling of temperature conditions near the bottom of well IDDP-1 in Krafla, Northeast Iceland. Geothermics 2014, 49, 49-57. [CrossRef]

100. Lamur, A.; Kendrick, J.E.; Eggertsson, G.H.; Wall, R.J.; Ashworth, J.D.; Lavallée, Y. The permeability of fractured rocks in pressurised volcanic and geothermal systems. Sci. Rep. 2017, 7, 6173. [CrossRef] [PubMed]

101. Mortensen, A.K.; Guðmundsson, A.; Steingrímsson, B.; Sigmundsson, F.; Axelsson, G.; Ármannsson, H.; Björnsson, H.; Ágústsson, K.; Sæmundsson, K.; Ólafsson, M.; et al. The Krafla geothermal system: Research summary and conceptual model revision. 2015. Available online: http:/ / gogn.lv.is/files/2015/2015-098.pdf (accessed on 9 February 2021).

102. Jóhannesson, H.; Saemundsson, K. Geological Map of Iceland. In Tectonics; Icelandic Institute of Natural History: Garðabær, Iceland, 1998.

103. Hjartardóttir, Á.R.; Einarsson, P.; Bramham, E.; Wright, T.J. The Krafla fissure swarm, Iceland, and its formation by rifting events. Bull. Volcanol. 2012, 74, 2139-2153. [CrossRef]

104. Einarsson, P. S-wave shadows in the Krafla caldera in NE-Iceland, evidence for a magma chamber in the crust. Bull. Volcanol. 1978, 41, 187-195. [CrossRef]

105. Ágústsson, K.; Flóvens, Ó.G.; Guðmundsson, Á.; Árnadóttir, Á. Induced Seismicity in the Krafla High Temperature Field. GRC Trans. 2012, 36, 975-980.

106. Ágústsson, K.; Blanck, H. Seismic Monitoring in Krafla, Námafjall and Theistareykir ), Open Report ÍSOR-2020/003. 2020. Available online: http:/ /gogn.lv.is/files/2020/2020-003.pdf (accessed on 9 February 2021).

107. Tibaldi, A.; Bonali, F.L.; Einarsson, P.; Hjartardóttir, Á.R.; Mariotto, F.A.P. Partitioning of Holocene kinematics and interaction between the Theistareykir Fissure Swarm and the Húsavík-Flatey Fault, North Iceland. J. Struct. Geol. 2016, 83, 134-155. [CrossRef]

108. Khodayar, M.; Björnsson, S.; Kristinsson, S.G.; Karlsdóttir, R.; Ólafsson, M.; Víkingsson, S. Tectonic Control of the Theistareykir Geothermal Field by Rift and Transform Zones in North Iceland: A Multidisciplinary Approach. J. Geol. 2018, 8, 543-584. [CrossRef]

109. Bonali, F.L.; Tibaldi, A.; Pasquaré Mariotto, F.; Saviano, D.; Meloni, A.; Sajovitz, P. Geometry, oblique kinematics and extensional strain variation along a diverging plate boundary: The example of the northern Theistareykir Fissure Swarm, NE Iceland. Tectonophysics 2019, 756, 57-72. [CrossRef]

110. Aydin, A. Fractures, faults, and hydrocarbon entrapment, migration and flow. Mar. Pet. Geol. 2000, 17, 797-814. [CrossRef]

111. Agosta, F.; Alessandroni, M.; Tondi, E.; Aydin, A. Oblique-slip normal faulting along the northern edge of the Majella anticline: Inferences on hydrocarbon migration and accumulation. J. Struct. Geol. 2009, 31, 1317-1333. [CrossRef]

112. Iadanza, A.; Sampalmieri, G.; Cipollari, P. Deep-seated hydrocarbons in the seep "Brecciated Limestones" of the Maiella area (Adriatic foreland basin): Evaporitic sealing and oil re-mobilization effects linked to the drawdown of the Messinian Salinity Crisis. Mar. Pet. Geol. 2015, 66, 177-191. [CrossRef]

113. Brogi, A.; Fulignati, P. Tectonic control on hydrothermal circulation and fluid evolution in the Pietratonda-Poggio Peloso (southern Tuscany, Italy) carbonate-hosted Sb-mineralization. Ore Geol. Rev. 2012, 44, 158-171. [CrossRef]

114. Capezzuoli, E.; Ruggieri, G.; Rimondi, V.; Brogi, A.; Liotta, D.; Alçiçek, M.C.; Alçiçek, H.; Bülbül, A.; Gandin, A.; Meccheri, M.; et al. Calcite veining and feeding conduits in a hydrothermal system: Insights from a natural section across the Pleistocene Gölemezli travertine depositional system (western Anatolia, Turkey). Sediment. Geol. 2018, 364, 180-203. [CrossRef]

115. Oliver, N.; Bons, P. Mechanisms of fluid flow and fluid-rock interaction in fossil metamorphic hydrothermal systems inferred from vein-wallrock patterns, geometry and microstructure. Geofluids 2001, 1, 137-162. [CrossRef]

116. Bons, P.D.; Elburg, M.A.; Gomez-Rivas, E. A review of the formation of tectonic veins and their microstructures. J. Struct. Geol. 2012, 43, 33-62. [CrossRef]

117. Gaweda, A.; Muller, A.; Stein, H.; Kadziolko-Gawel, M.; Mikulski, S. Age and origin of the tourmaline-rich hydraulic breccias in the Tatra Granite, Western Carpathians. J. Geosci. 2013, 58, 133-148. [CrossRef]

118. Waldhauser, F.; Schaff, D.P.; Diehl, T.; Engdahl, E.R. Splay faults imaged by fluid- driven aftershocks of the 2004 Mw 9.2 Sumatra-Andaman earthquake. Geology 2012, 40, 243-246. [CrossRef] 